\title{
The Influence of Household Wastewater Treatment Plants with Drainage System on the Quality of Groundwater in the Lublin Province, Poland
}

\author{
Krzysztof Jóźwiakowski ${ }^{*}$, Michał Marzec ${ }^{1}$, Agnieszka Listosz', \\ Magdalena Gizińska-Górna', Agnieszka Micek', Aneta Pytka', \\ Patrycja Pochwatka', Kamila Rybczyńska-Tkaczyk²
}

${ }^{1}$ Department of Environmental Engineering and Geodesy, University of Life Sciences in Lublin, ul. Leszczyńskiego 7, 20-069 Lublin, Poland

2 Department of Environmental Microbiology, Laboratory of Mycology, University of Life Sciences in Lublin, ul. Leszczyńskiego 7, 20-069 Lublin, Poland

* Corresponding author's email: krzysztof.jozwiakowski@up.lublin.pl

\begin{abstract}
The work presented the assessment of household wastewater treatment plants with drainage systems on the quality of groundwater in dug wells and deep water wells in the area of 3 selected communes (Drelów, Dębowa Kłoda and Urszulin), located in the Lublin province in south-eastern Poland. The investigations of the physicochemical composition of water from selected 28 dug wells and 2 deep water wells were conducted from June to July 2020, involving 9 measurement series. The microbiological studies consisted in 4 measurement series. The composition of the wastewater from primary settling tanks discharged to soil via drainage systems located in the vicinity of considered wells was also examined on a single occasion. The studies indicate that the water from wells are significantly polluted with ammonia, nitrites, as well as compounds of natural origin: iron and manganese. The presence of microbiological pollution of fecal origin was noted. The studies clearly indicate the possible pollution of the analyzed well waters with domestic sewage discharged to soil via drainage systems. Therefore, it necessary to take the actions aimed at improving the quality of groundwater in the Lublin province, including limitation of drainage systems, especially in the areas with unfavorable subsurface and hydrological conditions as well as low water supply coverage. The need to introduce changes in legal regulations and strategies for the development of technical infrastructure in counties, favoring the most efficient, as well as simple and inexpensive technologies, was indicated.
\end{abstract}

Keywords: household wastewater treatment plants, drainage system, water quality, wells, groundwater, physical and chemical pollutants, microbiological pollutants

\section{INTRODUCTION}

One of the prerequisites for maintaining good quality of environment in a given area is the creation of an appropriate water and sewage infrastructure. Despite a significant progress which occurred in the previous 20 years, the population of Poland, especially the people inhabiting rural areas, have a limited access to the water supply and sewage infrastructure. According to the data collected in 2018 by the Polish Central Statistical Office, $85 \%$ of people in rural areas had access to water supply network, whereas only $41 \%$ had access to a sewage system [GUS 2019a]. In turn, in the Lublin province, $80.6 \%$ of rural population was connected to a water supply network, but only $21.8 \%$ used a sewage system [Statistical Office in Lublin, 2019]. One of the main reasons for a slow development of the sewage infrastructure in rural areas of Poland, especially in the Lublin province, is the significant dispersal of settlements, which adds to the cost intensity of the investment process.

In accordance with the Water Act [2017] as well as the Announcement of the Marshal of the 
Sejm of the Republic of Poland 2020, installation of individual wastewater treatment systems, ensuring appropriate level of environmental protection, is recommended in the areas with low settlement aggregation index. Currently, the sewage in rural areas with dispersed settlements is accumulated in holding tanks and transported to collective treatment plants ( $90 \%$ of sewage) or treated in household wastewater treatment plants $(10 \%$ of sewage). The data of the Polish Central Statistical Office [2019b] indicate that by the end of 2018 there were 2163 thousand holding tanks and 257 thousand household wastewater treatment plants in Poland, $92 \%$ of which operated in rural areas. In recent years, household wastewater treatment plants have become increasingly popular element of sanitary infrastructure in rural areas of Poland [Pawełek, Bugajski 2017; Skrzypiec et al. 2017]. According to Mucha and Mikosz [2009] various criteria should be taken into account while considering the technological variants of household wastewater treatment plants, including: ecological (treatment efficiency), environmental (impact on the environment and aesthetics), technical (cutting edge solutions, simplicity and ease of operation), reliability (reliability of operation) and economic (investment and operational costs) criteria. However, with the current legal regulations pertaining to the construction of household wastewater treatment plants in Poland, the cost of purchase and installation remains the primary criterion while selecting the technology for treating small amounts of sewage. Therefore, the cheapest systems, which usually do not provide adequate protection for the groundwater resources, constitute the majority of household wastewater treatment plants. The questionnaire survey conducted in 2020 in 71 communes of the Lublin province indicates that among the employed technological solutions, the plants with drainage systems are most popular $(84.5 \%)$, followed by the plants with activated sludge (10.6\%) and constricted wetland systems $(2.5 \%)$, systems with biological bed $(1.2 \%)$ or hybrid systems (activated sludge + trickling filter) (1.2\%) (Figure 1).

The presented data indicate that the plants with drainage systems remain the most popular solution. The previously conducted questionnaire surveys showed that in the communes located in the Polesie and Roztocze National Parks, the plants with drainage systems constituted $85 \%$ and $93 \%$, respectively, among the technological solutions employed in household wastewater treatment plants [Jóźwiakowski et al. 2017; Jóźwiakowski et al. 2018]. Similarly high (>80\%) share of plants with drainage systems was also noted in the Parczew and Biała Podlaska counties, located in the Lublin province [Micek et al. 2018; Jóźwiakowska, Marzec 2020]. The questionnaire surveys previously carried out by Jóźwiakowski et al. [2012] in 70 communes located in the Lublin Province also indicated relatively high $(71 \%)$ share of drainage systems in the total number of technological solutions employed in household wastewater treatment plants.

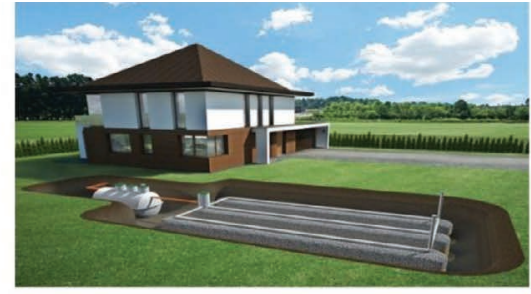

1 - with drainage system 7174 pcs $(84.3 \%)$

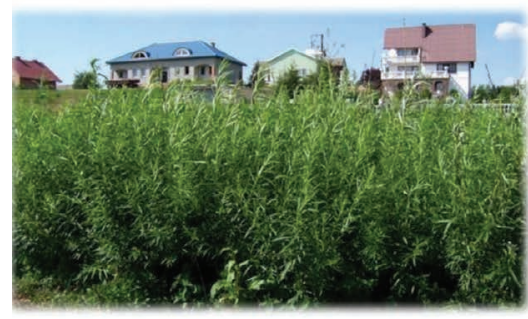

3 - constructed wetland systems 216 pcs $(2.5 \%)$
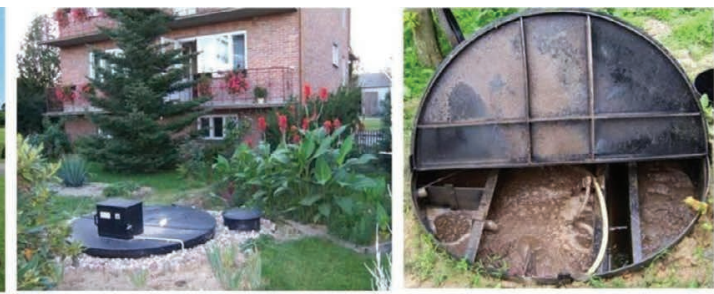

2 - with activated sludge 916 pes $(10.6 \%)$

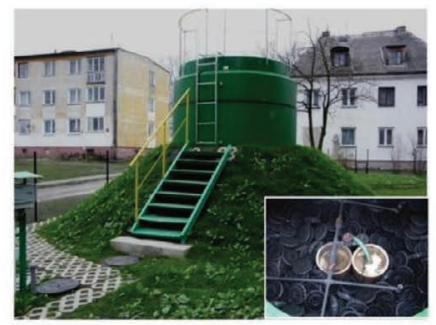

4 - systems with biological bed 104 pcs $(1.2 \%)$

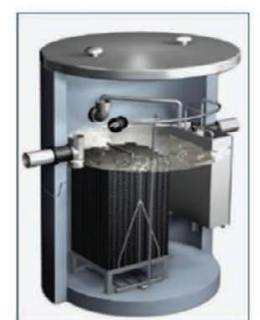

5 - hybrid systems $(2+4)$ $104 \operatorname{pcs}(1.2 \%)$

Figure 1. Kinds of household wastewater treatment plants in the Lublin province in 2020 
In Poland, the question whether the household wastewater treatment plants with drainage systems provide treatment or simply discharge non-treated sewage to soil, has been discussed for many years [Błażejewski 1995; Jucherski, Walczowski 2001; Paluch, Pulikowski 2004]. Application of this solution as a stand-alone system for treating small amounts of wastewater raises serious concerns, i.a. due to the lack of possibility of controlling its performance. It is also true that in such systems only mechanically treated sewage, containing substantial concentrations of organic, biogenic and microbiological pollution, is introduced to the environment, which may lead to soil and groundwater contamination. Obarska-Pempkowiak [2005] believes that septic tanks combined with drainage systems "constitute the solutions which are unacceptable in a longer time-span, because they directly discharge to receivers the wastewater which is treated only mechanically, and the rural areas in Poland are often characterized by low surface water resources, in which the capacity for receiving pollution loads is usually low".

The multi-annual studies performed by Jóźwiakowski [2003] indicated that the effects of treating wastewater in the plants with drainage system do not exceed $40 \%$ while in the case of $\mathrm{BOD}_{5}$ and COD, they reach up to $38 \%$. In turn, other studies conducted by Jóźwiakowski et al. [2014] in one of the communes of the Lublin province showed that wastewater treatment plants with drainage system located in the vicinity of dug and deep water wells had a negative influence on the quality of groundwater. Exceeded concentrations of chemical and microbiological indices were noted.

On the basis of a multicriteria analysis, Jóźwiakowski et al. [2015] indicated that taking into account the ecological criterion, the wastewater treatment plants with drainage system should not be used at a large scale, if sustainable development principles are to be met. In turn, numerous authors believe that the drainage systems should not be employed as a standalone wastewater treatment system, but they can be used for discharging biologically treated wastewater to soil [Walczowski 2013; Jóźwiakowski 2012a; Jóźwiakowski 2012b; Bugajski et al. 2017].

The lack of regulations connected with the selection of treatment technology, lenient requirements in terms of the quality of the wastewater discharged from household treatment plants to soil within the property borders, as well as the lack of legal and administrative bases for controlling the operation of household wastewater treatment plants contribute to large scale application of drainage systems and deterioration of the groundwater quality in Lublin province as well as in entire country. Further use of household wastewater treatment plants with drainage system may threaten the public health, especially the population using individual water intakes located within the areas of effect of these plants. Therefore, this subject was considered and investigations were carried out in order to prove that household wastewater treatment plants with drainage system should not be employed in Poland for treating small amounts of sewage.

The main objective of the studies was the assessment of the groundwater quality from individual water intakes, located in vicinity of household treatment plants with drainage systems, within the zone of their direct influence. The studies were conducted in 2020 in three communes of the Lublin province, which have recently realized the sanitation programs based on the plants with drainage systems.

\section{MATERIALS AND METHODS}

\section{Characteristics of the research objects}

The investigations on the quality of water from dug and deep water wells were carried out in 3 communes, i.e. Drelów, Dębowa Kłoda, and Urszulin, located in the Lublin province, southeastern Poland (Figure 2).

For the purpose of the research, 10 households were selected from each commune, based on two main criteria. The first criterion was the presence of an individual wastewater treatment plant with drainage system (Figure 1), whereas the second the presence of an individual groundwater intake in the form of a dug or deep water well. The wastewater treatment systems in all selected households are characterized by a similar design. The first element is a septic tank; this is where solid pollutants heavier than water undergo the sedimentation process and the initial processes of anaerobic decomposition occur. Moreover, the pollutants lighter than water undergo flotation forming scum on the surface of sewage. Another key element of wastewater treatment plants in the selected households is a distribution chamber with a dispersal system, laid 


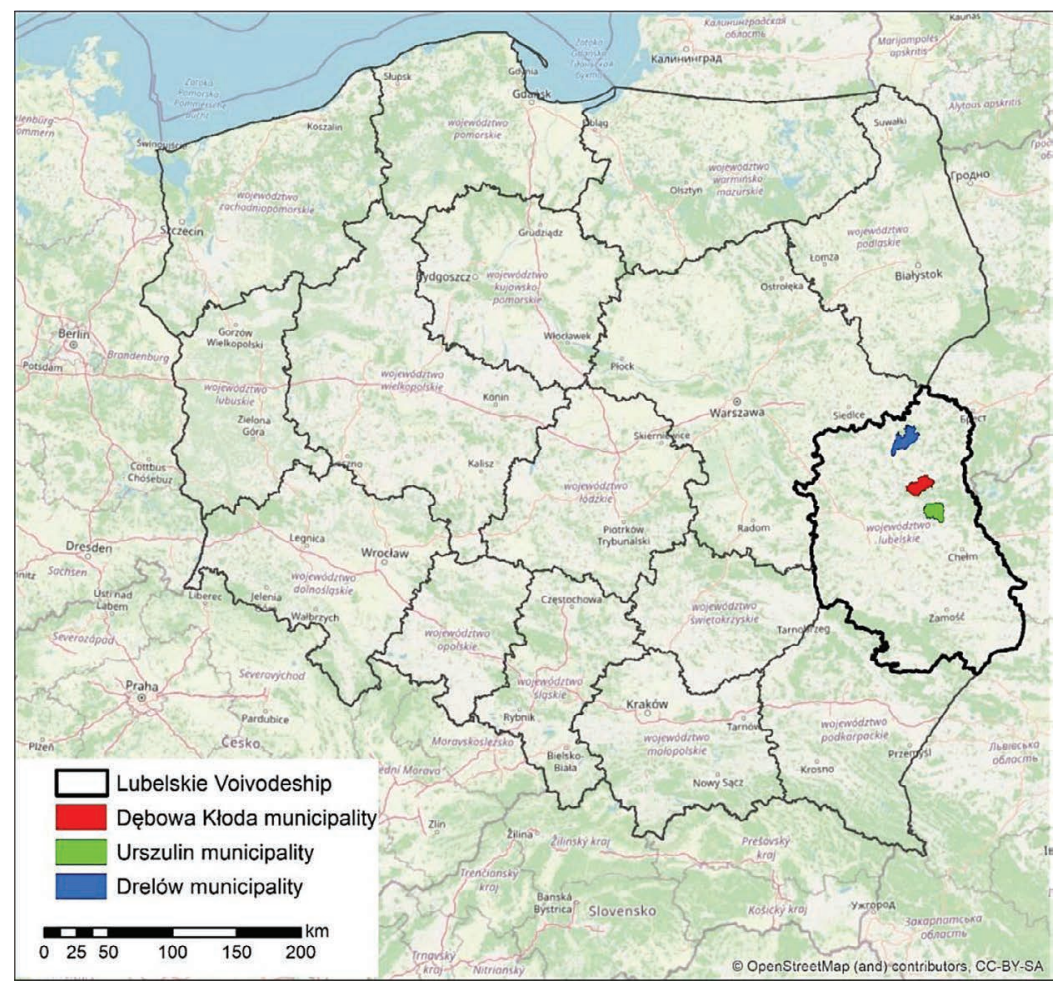

Figure 2. Location of communes in Poland involved in the investigation of the quality of water from wells in vicinity of wastewater treatment plants with drainage system

in ditches filled with coarse aggregate and vents installed at the end. The dispersal system discharges the mechanically treated wastewater to soil. In the considered technology, the wastewater flowing through a layer of aggregate are additionally treated before infiltrating into parent soil. In the majority of selected households, the septic tanks are additionally equipped with basket filters. They are installed at the septic tank outlet discharging wastewater into the distribution chamber. In the case of the high groundwater level between tanks and distribution chambers, sewage pumping stations were installed, which enabled to lay drainage at a lesser depth (Urszulin commune). The same problem was solved in some households in Drelów commune by installing tanks and drainage systems in fills. In such cases, the application of pumping stations for the raw sewage discharged from dwellings was necessary.

Drelów commune is located in the south-western part of the Biała Podlaska county in the Lublin Province (Figure 2). It spans over the area of 228.06 $\mathrm{km}^{2}$. This is a typical agricultural commune, with agricultural lands constituting over $56 \%$ of the area [District Council in Biała Podlaska 2018].

The questionnaire survey conducted in January 2020 indicates that the water supply network in the Drelów commune is poorly developed, used by $61.9 \%$ of population. In 2020 , the length of active water distribution network amounted to $109.74 \mathrm{~km}$. A significant part of inhabitants uses individual water intakes - dug and deep water wells. Clay loam soils, containing substantial amounts of manganese and iron, are dominant in the Drelów commune, negatively affecting the quality of groundwater. Therefore, the people using individual water intakes are forced to employ highly efficient water treatment systems.

There is no sewage infrastructure in the commune. According to the data of the Drelów Commune Office, at present there are about 550 septic tanks and 399 household wastewater treatment plants with drainage system in the households within this area. Ten households in the Drelów commune were selected for study, all of them located in Kwasówka (Figure 3).

The area of the commune is flat, and the groundwater table is relatively high. Its depth, determined on the basis of water level measurements in dug wells ranged during the investigation period (June - November 2020) from $0.7 \mathrm{~m}$ to $2.9 \mathrm{~m}$. During the installation of wastewater treatment plants with drainage system in the selected locations, the required distance from individual ground water intakes was usually not respected. It mostly ranges from 16 to $40 \mathrm{~m}$, exceeding $60 \mathrm{~m}$ only in a single 


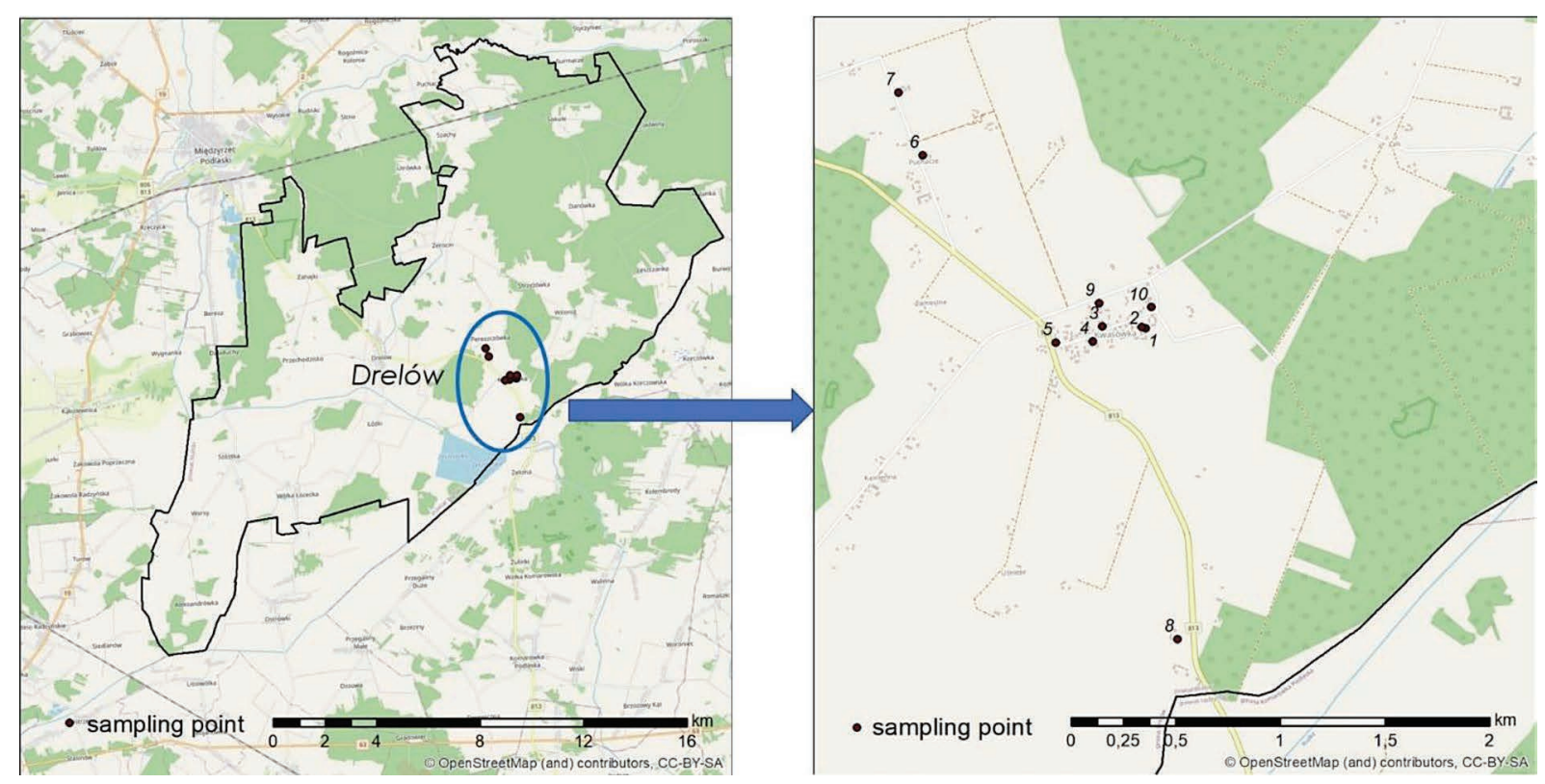

Figure 3. Location of groundwater sampling points in Drelów commune

case. The wells of the selected households include 8 dug wells and 2 deep water wells.

Dębowa Kloda commune is situated in the northern part of the Lublin province, in the Parczew county (Figure 2). Total area of the commune equals $188.37 \mathrm{~km}^{2}$, while population amounts to 4099. Almost $1 / 3$ of the Dębowa Kłoda commune is under protection [Dębowa Kłoda Commune Office 2015]. According to the data obtained in a questionnaire survey, length of active water supply network was $92.36 \mathrm{~km}$ in 2019. All towns within the commune are connected to a water supply network. Groundwater constitutes the main source of water supplied to households and for agricultural purposes. The commune also has a sewage network with a total length of $15.3 \mathrm{~km}$. Only $15.5 \%$ of residents had access to this network in 2019. Moreover, there are 732 individual sewage systems in the commune, which discharge sewage to holding tanks, periodically emptied by municipal services. There are 77 household wastewater treatment plants, 60 of which are equipped with a drainage system, 16 are plants with activated sludge and there is a single constructed wetland system. Ten households located in the Dębowa Kłoda commune, located in Chmielów, Bednarzówka, Nietiahy, Hanów and Kodeniec were selected for study (Figure 4). The area within the commune is flat. Groundwater level is high, which is reflected in all measurements of water table in dug wells. Within the research period (June - November 2020), the water table level in all locations ranged from $0.9 \mathrm{~m}$ to $2.9 \mathrm{~m}$, depending on the weather conditions. All investigated wells in Dębowa Kłoda are dug.

The household wastewater treatment plants operating in the Dębowa Kłoda households are located in vicinity of individual groundwater intakes. The distance between objects does not exceed $30 \mathrm{~m}$, approximating $10 \mathrm{~m}$ in some cases. Close vicinity of household treatment plants in relation to wells stems from the fact that they currently do not constitute a source of potable water for the inhabitants. Instead, the water from individual intakes is usually used for watering gardens, spray preparation, washing cars, agricultural machines, sometimes given to livestock.

Urszulin commune occupies the area of 172 $\mathrm{km}^{2}$ and lies in the central-eastern part of the Lublin province (Figure 2). According to the physical and geographical division of Poland, it lies in the central Łęczna-Włodawa Lakeland, which is part of Polesie Lubelskie, in turn being a part of Western Polesie. The landscape of Urszulin commune is characterized by numerous lakes, swamps, and peatlands with a high share of forest areas [Urszulin Commune Office].

In Urszulin, the water supply system is based on $117 \mathrm{~km}$ of water supply network, with $89.6 \%$ of population having access to it. In 2019, the length of sewage network amounted to $52.4 \mathrm{~km}$. Only $25.1 \%$ of inhabitants could discharge the sewage from their household using a collective system. The remainder uses holding tanks (612 pcs) or household wastewater treatment plants 


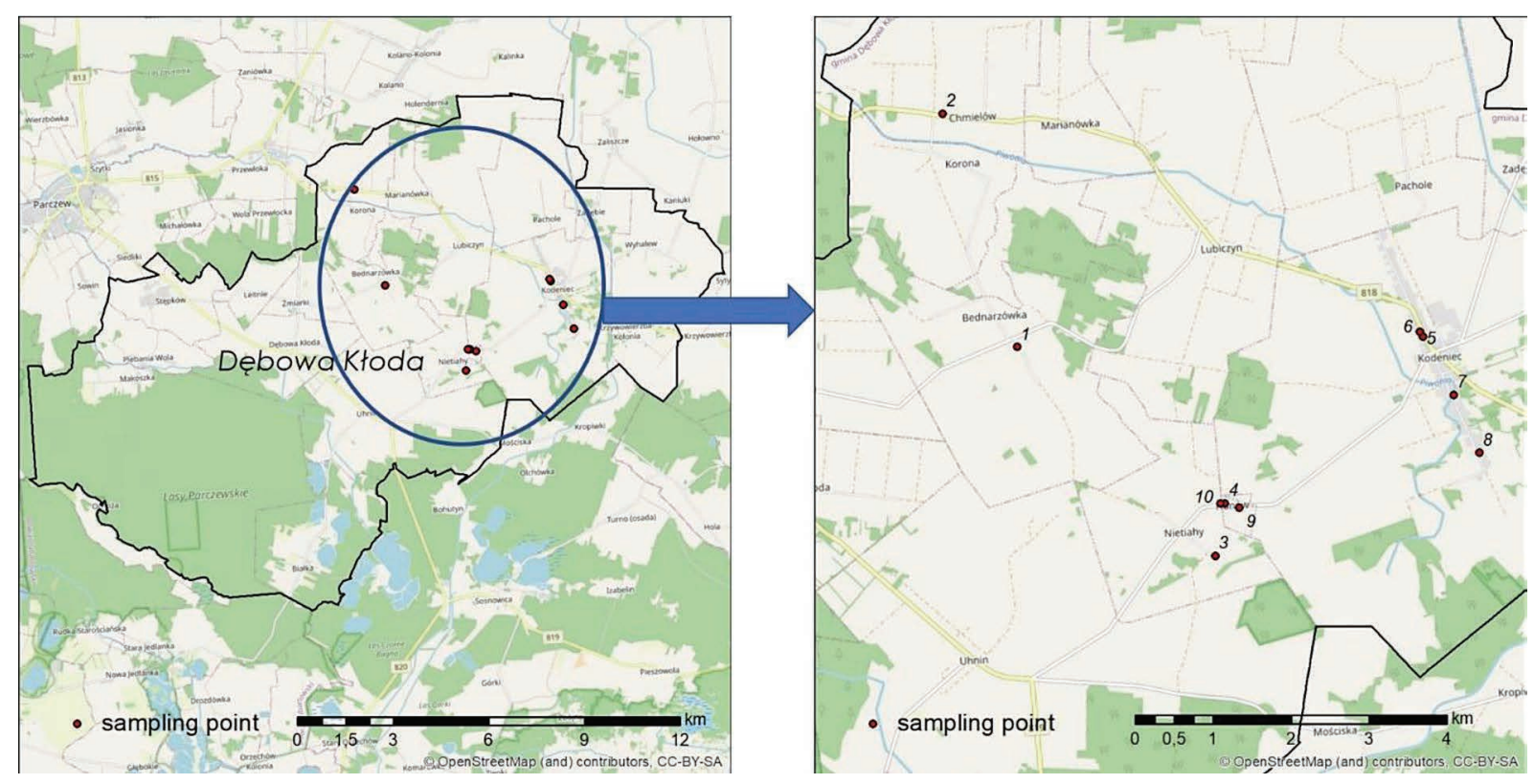

Figure 4. Location of groundwater sampling points in Dębowa Kłoda commune
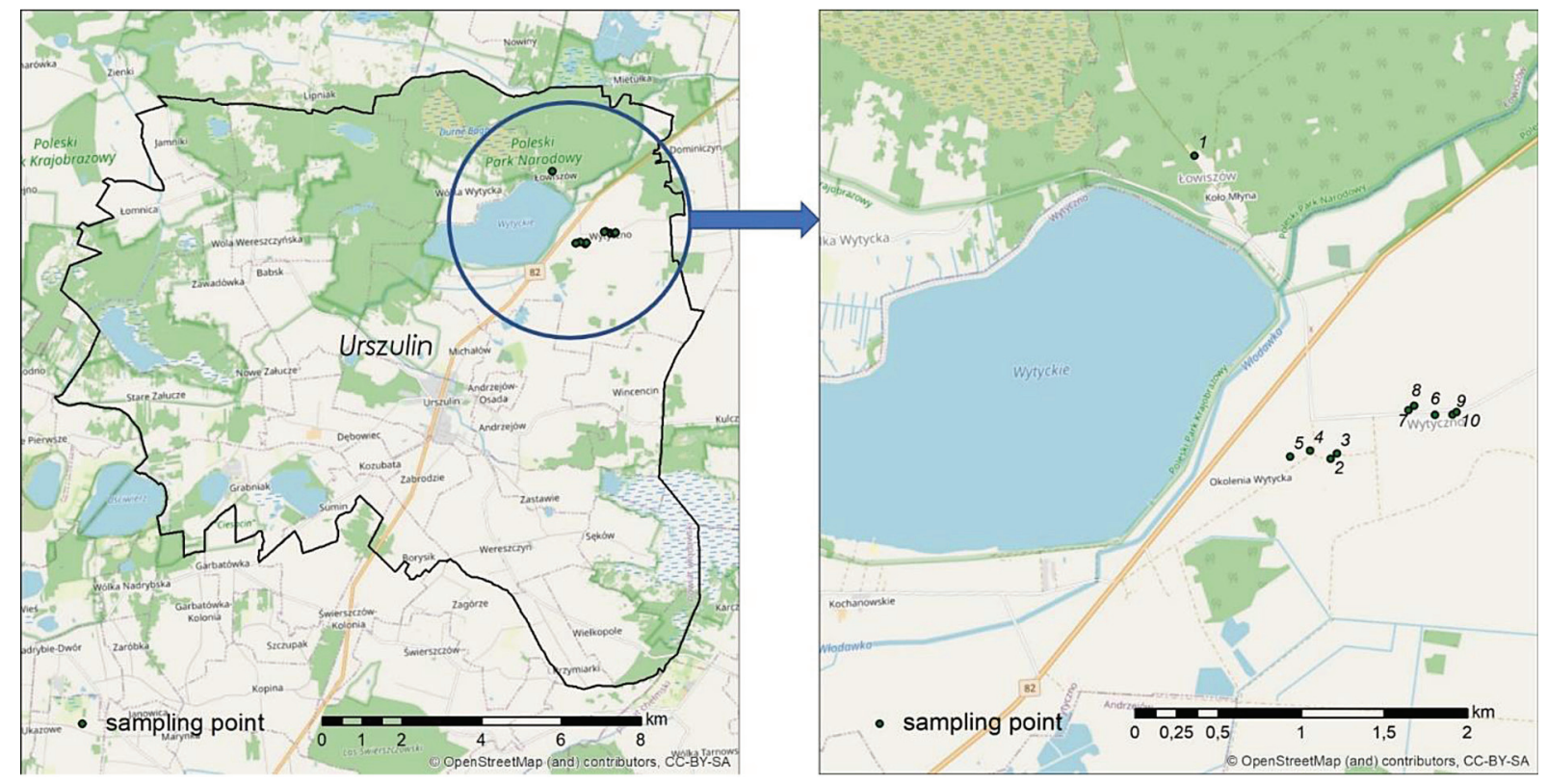

Figure 5. Location of groundwater sampling points in Urszulin commune

(83 pcs). All household treatment plants operating in Urszulin are equipped with drainage systems.

The households within the Urszulin commune selected for investigation are located in Wytyczno and Łowiszów (Figure 5). The examined area is characterized by relatively uniform topography. Since it is a wetland area, the groundwater level is close to the surface. In line with results of measurements performed from June to November 2020, the water table depth in dug wells ranged from $0.7 \mathrm{~m}$ to $3.9 \mathrm{~m}$. All analyzed wells were dug.

The distances in which household wastewater treatment plants are located from wells in all selected households do not exceed $40 \mathrm{~m}$, in some cases even $20 \mathrm{~m}$. This is because the water from individual intakes is usually used for watering gardens, spray preparation, washing cars, agricultural machines, sometimes given to livestock, rather than as potable water for people.

\section{RESEARCH METHODOLOGY}

The samples of water from wells located in Drelów, Dębowa Kłoda and Urszulin communes used in the physicochemical analyses were 
collected from June to November 2020 in two to three week intervals. In total, 9 measurement series were performed in that period. In turn, the microbiological studies involved 4 measurement series. The laboratory analyses were conducted on water collected from 28 dug wells and 2 deep water wells.

The physicochemical analyses of groundwater consisted in determining:

- $\mathrm{pH}$ value - determined with an ORION Star A329 Set portable multi-parameter meter by Thermo Scientific,

- conductivity - determined by means of an ORION Star A329 Set portable multi-parameter meter by Thermo Scientific,

- nitrates, nitrites, ammonia, chlorides, sulfates, iron, manganese, total harness, orthophosphates - determined with a NANOCOLOR ${ }^{\circledR}$ UV-VIS spectrophotometer by Macherey-Nagel.

The microbiological studies of waters consisted in determining the number of coliform bacteria and fecal coliform. The coliform bacteria are non-spore forming Gram-negative rods belonging to the Escherichia, Citrobacter, Enterobacter and Klebsiella genera, developing under relatively anaerobic conditions, fermenting lactose while simultaneously generating acid and gas over 24$48 \mathrm{~h}$ at a temperature of $35-37^{\circ} \mathrm{C}$. The fecal coliform bacteria found in sewage mainly include Escherichia coli which are found in abundance in human feces, capable of fermenting lactose while producing acid and gas at a temperature of $44^{\circ} \mathrm{C}$.

In the collected water samples, the presence of coliform bacteria was determined with the fermentation method, while the fecal coliform bacteria were detected by $1 / 10$ binary serial dilution on liquid Eijkman lactose medium and bromocreosol purple in vials with Dürham tubes, and then incubating at a temperature of $37^{\circ} \mathrm{C}$ and $44^{\circ} \mathrm{C}$. The results were read after 24 and $48 \mathrm{~h}$. A complete change in medium color (purple to yellow) and gas generation were assumed as the positive result. The number of coliform and fecal coliform bacteria (in $100 \mathrm{ml}$ ) was determined with the most probable number method (MPN).

The performed studies also involved determining the depth of water table in the analyzed wells by means of a hydrogeological whistle. Moreover, the physicochemical and microbiological composition of effluent wastewater from primary settling tanks of household wastewater treatment plants discharged to soil in vicinity of the investigated wells was analyzed on a single occasion. These analyses involved determination of the following pollution indices:

- Total suspended solids - direct gravimetric method using filters.

- Dissolved oxygen concentration - determined with an ORION Star A329 Set portable multiparameter meter by Thermo Scientific.

- $\mathrm{pH}$ - determined with an ORION Star A329 Set portable multi-parameter meter by Thermo Scientific.

- $\mathrm{BOD}_{5}-$ serial dilution and inoculation with allylothiourea. During $\mathrm{BOD}_{5}$ determination, the oxygen concentration was performed using an ORION Star A329 Set portable multiparameter meter by Thermo Scientific directly after sample collection and following 5 days of incubation at a temperature of $20^{\circ} \mathrm{C}$ in an incubator.

- $\mathrm{COD}_{\mathrm{Cr}}$ - bichromate method using vial tests (COD was determined by means of a NANOCOLOR $^{\circledR} \quad$ UV/VIS spectrophotometer by Macherey-Nagel, following prior oxidation of the investigated sample in a thermoreactor at a temperature of $148^{\circ} \mathrm{C}$ ).

- Total nitrogen - spectrophotometric method using vial tests; the samples were heated for 30 minutes in a thermoreactor at a temperature of $120^{\circ} \mathrm{C}$. The measurement was performed by means of a NANOCOLOR ${ }^{\circledR}$ UV-VIS spectrophotometer.

- Total phosphorus - spectrophotometric method using vial tests; the samples were heated for 30 minutes in a thermoreactor at a temperature of $120^{\circ} \mathrm{C}$. The measurement was performed by means of a NANOCOLOR ${ }^{\circledR}$ UVVIS spectrophotometer.

- Ammonia nitrogen - spectrophotometric method using vial tests, determination was performed using a NANOCOLOR ${ }^{\circledR}$ UV-VIS spectrophotometer.

- Nitrate and nitrite nitrogen - spectrophotometric methods with cuvette tests, determination using a NANOCOLOR ${ }^{\circledR}$ UV-VIS, spectrophotometer.

- Chlorides and sulfates - spectrophotometric methods with vial and cuvette tests, determination using a NANOCOLOR ${ }^{\circledR}$ UV-VIS, spectrophotometer.

- Number of coliform and fecal coliform bacteria - the same methods as in the case of groundwater. 
The physicochemical analyses were performed using the commonly employed methods [Dojlido et al. 1999]. On the basis of the results obtained from the physicochemical studies of groundwater from individual sources, the characteristic values of pollution indices were determined, including the mean, minimum, maximum and median values, standard deviations and coefficients of variation. The obtained results were related to the requirements in the Regulation of the Minister of Health of $7^{\text {th }}$ December 2017 on the quality of water intended for human consumption [Dz. U. 2017, item 2294].

\section{RESULTS AND DISCUSION}

\section{Composition of wastewater discharged to soil from household wastewater treatment plants}

Tables 1-3 present the physicochemical composition of wastewater discharged to soil from the primary settling tanks of household wastewater treatment plants with drainage system, located in the vicinity of investigated wells in 3 selected communes in the Lublin province.

Temperature. According to Heidrich and Stańko [2007], the temperature of wastewater in household treatment plants does not usually drop below $10^{\circ} \mathrm{C}$, and its value in particular seasons is to some extent dependent on the air temperature. The authors reported that for the air temperature $>16^{\circ} \mathrm{C}$, the temperature of wastewater ranges from 16.1 to $18.0^{\circ} \mathrm{C}$. In the analyzed wastewater discharged to soil from primary settling tank, the temperature ranged from 19.8 to $20.5^{\circ} \mathrm{C}$, on average.

$\mathbf{p H}$. According to the literature data, the value of $\mathrm{pH}$ for typical household wastewater is usually in the range of 6.6-8.0 [Dymaczewski et al. 1997; Heidrich, Stańko 2007]. The performed studies indicate that the $\mathrm{pH}$ of the analyzed wastewater was usually in the above-mentioned range, reaching from 6.19 to $7.57 \mathrm{pH}$, i.e. mildly acidic or mildly alkaline. Similar values of $\mathrm{pH}(6.35-7.64)$ were noted previously [Jóźwiakowski 2012] in mechanically treated wastewater in 2 primary settling tanks, whereas slightly higher values $(\mathrm{pH}$ 7.31-8.07) were observed in the mechanically treated wastewater in 4 primary settling tanks studied by Micek et al. [2020].

Dissolved oxygen. In fresh wastewater, the concentration of oxygen may reach several mg $\mathrm{O}_{2} / \mathrm{dm}^{3}$, whereas in putrid wastewater, stored in a settling tank for a long period of time, the oxygen concentration drops well below $0.5 \mathrm{mg} \mathrm{O}_{2}$ ' $\mathrm{dm}^{3}$ [Heidrich et al. 2008]. It was calculated that the mean concentrations of dissolved oxygen in the wastewater discharged from primary settling tank to soil reached from 0.57 to $0.96 \mathrm{mg} \mathrm{O}_{2} / \mathrm{dm}^{3}$ (Tables 1-3). Similar $\mathrm{O}_{2}$ concentrations (0.46 to $0.52 \mathrm{mg} \mathrm{O}_{2} / \mathrm{dm}^{3}$ ) were obtained by Jóźwiakowski [2012] in the wastewater following mechanical treatment in primary settling tanks of 2 household wastewater treatment plants. In turn, much higher dissolved oxygen concentrations ( 0.50 to $1.62 \mathrm{mg}$ $\mathrm{O}_{2} / \mathrm{dm}^{3}$ ) were observed by Micek et al. [2020] in the mechanically treated wastewater from 4 primary settling tanks.

Total suspended solids are a measure of total amount of pollutants present in wastewater in solid form [Heidrich, Stańko 2007]. On the basis of the obtained results, it was calculated that the mean content of total suspended solids in the wastewater discharged from primary settling tanks to soil in the area of 3 selected communes amounted to: 105, 190, and $236 \mathrm{mg} / \mathrm{dm}^{3}$ (Tables

Table 1. Composition of wastewater discharged to soil in the vicinity of investigated wells in Drelów commune

\begin{tabular}{|c|c|c|c|c|c|c|c|c|c|c|c|}
\hline \multirow{2}{*}{ Parameters } & \multicolumn{11}{|c|}{ Number of object } \\
\hline & 1 & 2 & 3 & 4 & 5 & 6 & 7 & 8 & 9 & 10 & Mean \\
\hline Temperature $\left[{ }^{\circ} \mathrm{C}\right]$ & 20.8 & 20.8 & 20.4 & 17.8 & 20.4 & 20.6 & 20.8 & 20.8 & 20.7 & - & 20.3 \\
\hline $\mathrm{pH}$ & 7.25 & 7.25 & 7.57 & 7.36 & 6.9 & 6.8 & 6.77 & 6.71 & 6.19 & - & - \\
\hline Dissolved oxygen $\left[\mathrm{mg} \mathrm{O}_{2} / \mathrm{dm}^{3}\right]$ & 0.77 & 0.77 & 0.06 & 1.04 & 0.08 & 0.1 & 0.83 & 2.15 & 2.62 & - & 0.96 \\
\hline $\mathrm{TSS}\left[\mathrm{mg} / \mathrm{dm}^{3}\right]$ & 71 & 71 & 34 & - & 105 & 86 & 110 & 165 & 168 & - & 106 \\
\hline $\mathrm{BOD}_{5}\left[\mathrm{mg} \mathrm{O}_{2} / \mathrm{dm}^{3}\right]$ & 335 & 335 & 250 & 164 & 455 & 383 & 298 & 506 & 572 & - & 370 \\
\hline $\mathrm{COD}\left[\mathrm{mg} \mathrm{O}_{2} / \mathrm{dm}^{3}\right]$ & 737 & 737 & 592 & 626 & 1143 & 1030 & 743 & 1359 & 1711 & - & 993 \\
\hline Nitrate nigtrogen $\left[\mathrm{mg} / \mathrm{dm}^{3}\right]$ & 0.5 & 0.5 & 0.5 & 0.9 & 0.5 & 1.2 & 0.5 & 1 & 2.4 & - & 0.94 \\
\hline Nitrite nitrogen $\left[\mathrm{mg} / \mathrm{dm}^{3}\right]$ & 0.15 & 0.15 & 0.15 & 0.21 & 0.12 & 0.28 & 0.14 & 0.33 & 0.32 & - & 0.21 \\
\hline Ammonium nitrogen $\left[\mathrm{mg} / \mathrm{dm}^{3}\right]$ & 108 & 108 & 133 & 211 & 245 & 103 & 85 & 128 & 109 & - & 140 \\
\hline Total nitrogen $\left[\mathrm{mg} / \mathrm{dm}^{3}\right]$ & 127 & 127 & 146 & 250 & 267 & 132 & 106 & 184 & 152 & - & 170 \\
\hline Total phosphorus [mg/dm³] & 16 & 16 & 15.6 & 23.3 & 22.3 & 15 & 11.9 & 21.3 & 26.7 & - & 19.0 \\
\hline Sulfates $\left[\mathrm{mg} / \mathrm{dm}^{3}\right]$ & 166 & 166 & 61 & 97 & 175 & 209 & 72 & 171 & 101 & - & 131 \\
\hline Chlorides [mg/dm $\left.{ }^{3}\right]$ & 1307 & 1307 & 491 & 469 & 2450 & 1206 & 417 & 4566 & 471 & - & 1422 \\
\hline
\end{tabular}


Table 2. Composition of wastewater discharged to soil in the vicinity of investigated wells in Dębowa Kłoda commune

\begin{tabular}{|c|c|c|c|c|c|c|c|c|c|c|c|}
\hline \multirow{2}{*}{ Parameters } & \multicolumn{11}{|c|}{ Number of object } \\
\hline & 1 & 2 & 3 & 4 & 5 & 6 & 7 & 8 & 9 & 10 & Mean \\
\hline Temperature $\left[{ }^{\circ} \mathrm{C}\right]$ & 19.9 & 19.8 & 20.0 & 19.6 & - & 19.4 & 19.4 & 19.8 & - & 20.3 & 19,8 \\
\hline $\mathrm{pH}$ & 6.84 & 6.75 & 6.92 & 6.79 & - & 6.84 & 7.27 & 7.38 & - & 7.17 & - \\
\hline Dissolved oxygen $\left[\mathrm{mg} \mathrm{O}_{2} / \mathrm{dm}^{3}\right]$ & 1.1 & 1 & 0.92 & 0.99 & - & 0.09 & 1.35 & 0.84 & - & 0.18 & 0.81 \\
\hline TSS $\left[\mathrm{mg} / \mathrm{dm}^{3}\right]$ & 200 & 136 & 161 & 186 & - & 136 & 135 & 178 & 210 & 361 & 190 \\
\hline $\mathrm{BOD}_{5}\left[\mathrm{mg} \mathrm{O}_{2} / \mathrm{dm}^{3}\right]$ & 259 & 329 & 291 & - & - & 603 & 556 & 549 & 665 & 539 & 474 \\
\hline $\mathrm{COD}\left[\mathrm{mg} \mathrm{O}_{2} / \mathrm{dm}^{3}\right]$ & 543 & 1076 & 613 & 1024 & - & 1209 & 980 & 1239 & 1470 & 1490 & 1072 \\
\hline Nitrate nigtrogen $\left[\mathrm{mg} / \mathrm{dm}^{3}\right]$ & 1.6 & 2.6 & 1.2 & 1.9 & - & 2.7 & 1.2 & 2.2 & 4.4 & 2.8 & 2.29 \\
\hline Nitrite nitrogen $\left[\mathrm{mg} / \mathrm{dm}^{3}\right]$ & 0.15 & 0.22 & 0.1 & 0.16 & - & 0.24 & 0.11 & 0.17 & 0.52 & 0.26 & 0.21 \\
\hline Ammonium nitrogen [mg/dm³ & 70 & 121 & 89 & 110 & - & 161 & 258 & 248 & 137 & 215 & 157 \\
\hline Total nitrogen $\left[\mathrm{mg} / \mathrm{dm}^{3}\right]$ & 72.2 & 144 & 105 & 139 & - & 226 & 281 & 261 & 180 & 228 & 182 \\
\hline Total phosphorus [mg/dm $\left.{ }^{3}\right]$ & 2.72 & 6.11 & 3.48 & 4.96 & - & 9.32 & 8.07 & 9.74 & 7.22 & 8.63 & 6.7 \\
\hline Sulfates $\left[\mathrm{mg} / \mathrm{dm}^{3}\right]$ & 102 & 108 & 99 & 131 & - & 192 & 77 & 73 & 109 & 62 & 106 \\
\hline Chlorides [mg/dm $\left.{ }^{3}\right]$ & 1386 & 1486 & 1498 & 3597 & - & 1290 & 1496 & 3851 & 3448 & 2878 & 2326 \\
\hline
\end{tabular}

Table 3. Composition of wastewater discharged to soil in the vicinity of investigated wells in Urszulin commune

\begin{tabular}{|c|c|c|c|c|c|c|c|c|c|c|c|}
\hline \multirow{2}{*}{ Parameters } & \multicolumn{11}{|c|}{ Number of object } \\
\hline & 1 & 2 & 3 & 4 & 5 & 6 & 7 & 8 & 9 & 10 & Mean \\
\hline Temperature $\left[{ }^{\circ} \mathrm{C}\right]$ & 20.7 & 20.8 & 20.9 & 21 & 20.7 & 20.5 & 20.4 & 20 & 20.1 & 20.2 & 20.5 \\
\hline $\mathrm{pH}$ & 6.95 & 7.24 & 7.02 & 6.94 & 7.08 & 7.12 & 6.88 & 6.81 & 7.14 & 7.00 & - \\
\hline Dissolved oxygen $\left[\mathrm{mg} \mathrm{O}_{2} / \mathrm{dm}^{3}\right]$ & 0.97 & 0.24 & 0.15 & 1.22 & 2.09 & 0.06 & 0.21 & 0.53 & 0.13 & 0.11 & 0.57 \\
\hline $\mathrm{TSS}\left[\mathrm{mg} / \mathrm{dm}^{3}\right]$ & 161 & 204 & 213 & 149 & 129 & 225 & 180 & 461 & 183 & 450 & 236 \\
\hline $\mathrm{BOD}_{5}\left[\mathrm{mg} \mathrm{O}_{2} / \mathrm{dm}^{3}\right]$ & 176 & 232 & 194 & 446 & 251 & 433 & 171 & 146 & 159 & 170 & 238 \\
\hline $\mathrm{COD}\left[\mathrm{mg} \mathrm{O}_{2} / \mathrm{dm}^{3}\right]$ & 445 & 637 & 592 & 1169 & 667 & 1043 & 680 & 672 & 662 & 735 & 730 \\
\hline Nitrate nigtrogen $\left[\mathrm{mg} / \mathrm{dm}^{3}\right]$ & 0.1 & 0.1 & 0.1 & 1.0 & 0.1 & 0.1 & 0.1 & 0.1 & 0.4 & 0.6 & 0.27 \\
\hline Nitrite nitrogen $\left[\mathrm{mg} / \mathrm{dm}^{3}\right]$ & 0.04 & 0.15 & 0.17 & 0.36 & 0.15 & 0.32 & 0.07 & 0.14 & 0.12 & 0.18 & 0.17 \\
\hline Ammonium nitrogen [mg/dm³] & 143 & 143 & 130 & 156 & 92 & 105 & 194 & 157 & 84 & 156 & 136 \\
\hline Total nitrogen $\left[\mathrm{mg} / \mathrm{dm}^{3}\right]$ & 167 & 197 & 157 & 213 & 117 & 141 & 232 & 182 & 114 & 166 & 169 \\
\hline Total phosphorus [mg/dm³] & 15.2 & 16.9 & 17.6 & 26.8 & 9.42 & 16.5 & 19.6 & 15 & 18.5 & 20.3 & 17.6 \\
\hline Sulfates $\left[\mathrm{mg} / \mathrm{dm}^{3}\right]$ & - & 198 & 189 & 189 & 133 & 198 & 224 & - & 225 & 119 & 184 \\
\hline Chlorides $\left[\mathrm{mg} / \mathrm{dm}^{3}\right]$ & - & 1572 & 4888 & 1087 & 614 & 4928 & 434 & - & 447 & 1313 & 1910 \\
\hline
\end{tabular}

1-3). Similar concentrations of total suspended solids $\left(100-206 \mathrm{mg} / \mathrm{dm}^{3}\right)$ were noted earlier in the mechanically treated wastewater, flowing into constructed wetland systems in the Lublin province [Jóźwiakowski et al. 2019]. Much lower values $\left(29-112 \mathrm{mg} / \mathrm{dm}^{3}\right)$ were noted in the mechanically treated wastewater in four 3- and 4-chamber primary settling tanks in the area of Roztocze National Park [Micek et al. 2020]. The total suspended solids content in the analyzed wastewater introduced through drainage systems to soil in 3 selected communes in the Lublin province were over $2-4$-fold greater than the permissible value $\left(50 \mathrm{mg} / \mathrm{dm}^{3}\right)$, determined by the Regulation of the Minister of Maritime Economy and Inland Navigation from 2019.

BOD $_{5}$ is one of the most important indices of wastewater pollution with organic substances [Heidrich et al. 2008]. The investigations of mechanically treated wastewater discharged from primary settling tanks to soil in 3 selected communes in the Lublin province indicated that mean $\mathrm{BOD}_{5}$ values amounted to 370,474 , and $238 \mathrm{mg} \mathrm{O}_{2} / \mathrm{dm}^{3}$, respectively (Tables $1-3$ ). Similar mean value of $\mathrm{BOD}_{5}\left(417 \mathrm{mg} \mathrm{\textrm {O } _ { 2 }} / \mathrm{dm}^{3}\right)$ was observed in the mechanically treated wastewater in primary settling tanks studied by Jóźwiakowski et al. [2019], whereas much lower concentrations (53-281 $\mathrm{mg} \mathrm{O}_{2} / \mathrm{dm}^{3}$ ) were found in the wastewater treated mechanically in four 3- and 4-chamber primary settling tanks in the area of Roztocze National Park [Micek et al. 2020]. The values of $\mathrm{BOD}_{5}$ in the analyzed wastewater introduced by drainage systems to soil in the area of 3 selected communes in Lublin province were over 6-12-fold greater than the permissible value $\left(40 \mathrm{mg} \mathrm{O} / \mathrm{dm}^{3}\right.$ ) determined by Regulation of the Minister of Maritime Economy and Inland Navigation from 2019.

COD is an index which enables a quick control of plant operation as well as determination of the load of organic substances discharged to the receiver [Heidrich et al. 2008]. The studies 
performed in 3 selected communes in the Lublin province indicate that the COD values in mechanically treated wastewater discharged from primary settling tanks to soil were very high and reached 993, 1072 and $730 \mathrm{mg} \mathrm{O}_{2} / \mathrm{dm}^{3}$, respectively (Tables 1-3). Much lower mean COD value (780 $\mathrm{mg} \mathrm{O}_{2} / \mathrm{dm}^{3}$ ) was noted in the mechanically treated wastewater in primary settling tanks by Jóźwiakowski et al. [2019], as well as in the mechanically treated wastewater (180-810 $\mathrm{mg} \mathrm{O}_{2} /$ $\mathrm{dm}^{3}$ ) from four 3- and 4-chamber primary settling tanks in the area of Roztocze National Park [Micek et al. 2020]. The values of COD in the analyzed wastewater discharged through drainage systems to soil in the area of 3 selected communes in the Lublin province were over 6-7-fold greater than the permissible value $\left(150 \mathrm{mg} \mathrm{O}_{2} / \mathrm{dm}^{3}\right)$, determined in the Regulation of the Minister of Maritime Economy and Inland Navigation from 2019.

Nitrogen and its compounds. The nitrogen compounds contained in household wastewater are mainly connected with organic pollutants [Heidrich et al. 2008]. The studies conducted in 3 communes in the Lublin province showed that in the mechanically treated wastewater discharged to soil, ammonia nitrogen was dominant (136$157 \mathrm{mg} / \mathrm{dm}^{3}$ ), whereas other nitrogen compounds (nitrate and nitrite nitrogen) were present in small amounts $\left(<2.3 \mathrm{mg} / \mathrm{dm}^{3}\right)$ (Tables 1-3). In turn, the mean concentrations of total nitrogen in the investigated wastewater amounted to: 170,182 , and $169 \mathrm{mg} / \mathrm{dm}^{3}$. Therefore, the obtained data indicate that after mechanical treatment, ammonia nitrogen is the dominant nitrogen form, constituting $80-86 \%$ of total nitrogen. Lower mean total nitrogen concentration $\left(151 \mathrm{mg} / \mathrm{dm}^{3}\right)$ were noted by Jóźwiakowski et al. [2019] in the wastewater following mechanical treatment in primary settling tanks, as well as by Micek et al. [2020] $\left(100-160 \mathrm{mg} / \mathrm{dm}^{3}\right)$, in the wastewater treated mechanically in primary settling tanks in Roztocze National Park. High concentrations of nitrogen in the wastewater discharged to water and soil may contribute to the degradation of surface and groundwater quality as well as the eutrophication process [Jóźwiakowski et al. 2014]. Therefore, further biological treatment is necessary, which is not possible in household wastewater treatment plants with drainage system [Orlik, Jóźwiakowski 2003].

Phosphorus. According to Jarvie et al. [2006], phosphorus contained in wastewater is the main element initiating eutrophication of water; therefore, its efficient removal is necessary prior to discharge to a receiver. On the basis of the obtained research results, it can be stated that the mean total phosphorus concentration in the wastewater discharged from primary settling tanks to soil in the area of 3 selected communes amounted to $19.0,6.7$, and $17.6 \mathrm{mg} / \mathrm{dm}^{3}$, respectively (Tables 1-3). Similar concentrations of total phosphorus were noted in the wastewater treated mechanically in primary settling tank (12.0-26.2 $\mathrm{mg} / \mathrm{dm}^{3}$ ) in the area of Roztocze National Park investigated by Micek et al. [2020]. In turn, much higher mean total phosphorus concentration $\left(31.6 \mathrm{mg} / \mathrm{dm}^{3}\right)$ was noted earlier in the mechanically treated wastewater flowing into constructed wetland systems in the Lublin province [Jóźwiakowski et al. 2019].

Chlorides and sulfates are indices of anthropogenic pollution, which indicate the presence of wastewater in surface and groundwater [Jóźwiakowska et al. 2020]. On the basis of the conducted studies it can be stated that the mean concentrations of chlorides and sulfates in the wastewater discharged from primary settling tanks to soil in 3 selected communes were very high and amounted to: 1422-2326 and 106-184 $\mathrm{mg} / \mathrm{dm}^{3}$, respectively (Tables $1-3$ ).

Coliform and fecal coliform bacteria in the wastewater introduced to soil. Tables 4-6 presents the count of coliform and fecal coliform bacteria in the wastewater discharged to soil from primary settling tanks of household wastewater treatment tanks with drainage system, located near the investigated wells in the area of 3 selected communes in the Lublin province.

The investigated wastewater contained substantial amounts of coliform bacteria. Their mean number in $100 \mathrm{ml}$ of wastewater ranged from 6.16 to $65.95 \cdot 10^{6}$; the highest mean number was obtained from the sampling points located in Drelów (Table 4). The number of fecal coliform bacteria in wastewater was usually several-fold lower, with the mean MPN ranging from $0.91 \cdot 10^{6}$ in $100 \mathrm{ml}$ of wastewater in Dębowa Kłoda to 2.77·10 in Drelów (Tables 4-6). Among the coliform bacteria, the Escherichia coli genus - which may contain pathogenic strains causing food poisoning, as well as urinary tract inflammation and meningitis - is dominant. In addition to food, which constitutes the main source of infection with $E$. coli bacteria, they are also found in water, sewage sludge and wastewater [Cabral 2010; Anastasi et al. 2012]. Previous studies indicated that the number of coliform bacteria in the wastewater 
Table 4. Count of coliform bacteria (incubation at $37^{\circ} \mathrm{C}$ ) and fecal coliform bacteria (incubation at $44^{\circ} \mathrm{C}$ ) in MPN/100 ml of wastewater from Drelów commune

\begin{tabular}{|c|c|c|c|c|c|c|c|c|c|}
\hline \multirow{2}{*}{ Parameters } & \multicolumn{9}{|c|}{ Number of object } \\
\hline & 1 and 2 & 3 & 4 & 5 & 6 & 7 & 8 & 9 & 10 \\
\hline $\begin{array}{l}\text { Coliform bacteria }\left(37^{\circ} \mathrm{C}\right) \\
\text { (MPN/100ml) }\end{array}$ & $1.4 \cdot 10^{8}$ & $4.5 \cdot 10^{7}$ & $4.5 \cdot 10^{6}$ & $2.5 \cdot 10^{7}$ & $1.4 \cdot 10^{8}$ & $2.5 \cdot 10^{7}$ & $1.4 \cdot 10^{8}$ & $1.4 \cdot 10^{8}$ & - \\
\hline $\begin{array}{l}\text { Fecal coliform bacteria } \\
\left(44^{\circ} \mathrm{C}\right)(\mathrm{MPN} / 100 \mathrm{ml})\end{array}$ & $1.5 \cdot 10^{4}$ & $2.5 \cdot 10^{6}$ & $7 \cdot 10^{5}$ & $2.5 \cdot 10^{6}$ & $7.5 \cdot 10^{6}$ & $4.5 \cdot 10^{6}$ & $7.5 \cdot 10^{6}$ & $2.5 \cdot 10^{6}$ & - \\
\hline
\end{tabular}

Table 5. Count of coliform bacteria (incubation at $37^{\circ} \mathrm{C}$ ) and fecal coliform bacteria (incubation at $44^{\circ} \mathrm{C}$ ) in MPN/100 ml of wastewater from Dębowa Kłoda commune

\begin{tabular}{|l|c|c|c|c|c|c|c|c|c|c|}
\hline \multicolumn{1}{|c|}{ Parameters } & 1 & 2 & 3 & 4 & 5 & 6 & 7 & 8 & 9 & 10 \\
\cline { 2 - 11 } & $7.5 \cdot 10^{7}$ & $2.5 \cdot 10^{7}$ & 0 & $4.5 \cdot 10^{6}$ & - & $4.5 \cdot 10^{6}$ & $4.5 \cdot 10^{6}$ & $4 \cdot 10^{5}$ & $4.5 \cdot 10^{6}$ & $4 \cdot 10^{5}$ \\
\hline $\begin{array}{l}\text { Coliform bacteria }\left(37^{\circ} \mathrm{C}\right) \\
(\mathrm{MPN} / 100 \mathrm{ml})\end{array}$ & $4 \cdot 10^{5}$ & $2.5 \cdot 10^{6}$ & $4 \cdot 10^{5}$ & 0 & - & 0 & $4 \cdot 10^{5}$ & $4 \cdot 10^{5}$ & $2.5 \cdot 10^{6}$ & $2.5 \cdot 10^{6}$ \\
\hline $\begin{array}{l}\text { Fecal coliform bacteria } \\
\left(44^{\circ} \mathrm{C}\right)(\mathrm{MPN} / 100 \mathrm{ml})\end{array}$ & & 0
\end{tabular}

Table 6. Count of coliform bacteria (incubation at $37^{\circ} \mathrm{C}$ ) and fecal coliform bacteria (incubation at $44^{\circ} \mathrm{C}$ ) in MPN/100 ml of wastewater from Urszulin commune

\begin{tabular}{|l|c|c|c|c|c|c|c|c|c|c|}
\hline \multicolumn{1}{|c|}{ Parameters } & 1 & 2 & 3 & 4 & 5 & 6 & 7 & 8 & 9 & 10 \\
\cline { 2 - 11 } & $4 \cdot 10^{5}$ & $2.5 \cdot 10^{6}$ & 0 & $2.5 \cdot 10^{6}$ & $2.5 \cdot 10^{6}$ & $1.4 \cdot 10^{8}$ & $4.5 \cdot 10^{6}$ & $3 \cdot 10^{5}$ & $2.5 \cdot 10^{7}$ & $2.5 \cdot 10^{7}$ \\
\hline $\begin{array}{l}\text { Coliform bacteria }\left(37^{\circ} \mathrm{C}\right) \\
(\mathrm{MPN} / 100 \mathrm{ml})\end{array}$ & $3 \cdot 10^{5}$ & 0 & 0 & $4.5 \cdot 10^{6}$ & 0 & 0 & $4.5 \cdot 10^{6}$ & 0 & $4 \cdot 10^{5}$ & $2.5 \cdot 10^{6}$ \\
\hline $\begin{array}{l}\text { Fecal coliform bacteria } \\
\left(44^{\circ} \mathrm{C}\right) \text { (MPN/100ml) }\end{array}$ & & 0 & 0 & 0 & 0 & 0
\end{tabular}

influent to household plants with drainage system in Lubraniec and Nakło communes ranged from $2.51 \cdot 10^{9}$ to $7.39 \cdot 10^{9}$ [Budzińska et al. 2007].

\section{Well water quality in the selected communes}

Tables 7-9 present the physicochemical composition of water from dug and deep water wells in vicinity of household wastewater treatment plants with drainage system, located in 3 selected communes in the Lublin province.

pH. The studies showed that the $\mathrm{pH}$ of water from all considered wells was slightly acidic or alkaline. In the water from wells in Drelów, the value of $\mathrm{pH}$ was in the range of 6.71-8.43, in Dębowa Kłoda it reached 6.50-7.97, whereas in Urszulin from 6.23 to 7.77 (Tables 7-9). The lowest $\mathrm{pH}$ (6.23) in the water from well no. 4 in Urszulin is lower than the minimum value established for the water intended for human consumption [Regulation of the Minister of Health, 2017]. This water is slightly acidic, possibly exhibiting corrosive properties. In 2013, a similar range of $\mathrm{pH}$ values (6.27-7.65) was observed in the water from wells in Drelów [Jóźwiakowski et al. 2014].

Specific conductivity. The conductivity values of the well waters were highly diversified, ranging from 196 to $1305 \mu \mathrm{S} / \mathrm{cm}$ in Drelów, from 274 to $1090 \mu \mathrm{S} / \mathrm{cm}$ in Dębowa Kłoda, and from 233 to $1248 \mu \mathrm{S} / \mathrm{cm}$ in Urszulin (Tables 7-9). IN 2013, a similar range of conductivity values (204-1264 $\mu \mathrm{S} / \mathrm{cm})$ was noted in dug and deep water wells in Drelów [Jóźwiakowski et al. 2014]. During the afore-mentioned study that the lowest conductivity values were obtained in dug wells.

Ammonia. The mean concentrations of ammonia in the waters from investigated wells ranged from 0.23 to $0.441 \mathrm{mg} / \mathrm{dm}^{3}$ in Drelów, from 0.020 to $0.116 \mathrm{mg} / \mathrm{dm}^{3}$ in Dębowa Kłoda, and from 0.010 to $1.043 \mathrm{mg} / \mathrm{dm}^{3}$ in Urszulin (Tables 7-9). The permissible ammonia content, established in the Regulation of the Minister of Health [2017] for the water intended for human consumption, amounting to $0.5 \mathrm{mg} / \mathrm{dm}^{3}$ was exceeded several-fold in the well waters in Drelów and Urszulin (Figure 6). In Drelów, elevated ammonia content was observed in the water from wells no. 1,8 , and 10 , whereas in Urszulin - in wells no. 8 and 9.

The presence of ammonia in well waters may be connected with the fact that the treatment plants with drainage system discharge to soil the wastewater treated only mechanically [Raczuk, Sarnowska 2002; Pawęska et al. 2012; Jóźwiakowski et al. 2014]. As it was mentioned above, the concentrations 
Table 7. Quality of groundwater from wells in Drelów commune (n=9)

\begin{tabular}{|c|c|c|c|c|c|c|c|c|c|c|c|}
\hline \multirow{2}{*}{ Parameters } & \multicolumn{11}{|c|}{ Number of well } \\
\hline & & 1 & 2 & 3 & 4 & 5 & 6 & 7 & 8 & 9 & 10 \\
\hline \multirow{6}{*}{$\begin{array}{l}\text { Depth of the } \\
\text { water table }\end{array}$} & $\overline{\mathrm{x}}$ & 2.33 & 22.00 & 2.47 & 18.00 & 2.03 & 2.30 & 2.67 & 1.61 & 2.03 & 2.02 \\
\hline & $\mathrm{Me}$ & 2.30 & 22.00 & 2.50 & 18.00 & 2.00 & 2.30 & 2.70 & 1.30 & 2.00 & 2.10 \\
\hline & Min & 1.80 & 22.00 & 2.10 & 18.00 & 1.80 & 2.00 & 2.30 & 0.70 & 1.80 & 1.80 \\
\hline & $\operatorname{Max}$ & 2.80 & 22.00 & 2.80 & 18.00 & 2.30 & 2.60 & 2.90 & 2.90 & 2.30 & 2.30 \\
\hline & SD & 0.32 & 0.0 & 0.19 & 0.00 & 0.14 & 0.30 & 0.17 & 0.61 & 0.14 & 0.15 \\
\hline & $\mathrm{Cv}$ & 13.70 & 0.00 & 7.88 & 0.00 & 6.96 & 13.04 & 6.37 & 38.09 & 6.96 & 7.65 \\
\hline \multirow{6}{*}{$\mathrm{pH}$} & $\overline{\mathrm{x}}$ & - & - & - & - & - & - & - & - & - & - \\
\hline & $\mathrm{Me}$ & - & - & - & - & - & - & - & - & - & - \\
\hline & Min & 7.03 & 6.88 & 6.74 & 7.19 & 6.85 & 6.70 & 7.27 & 7.20 & 7.06 & 6.71 \\
\hline & $\operatorname{Max}$ & 8.43 & 8.30 & 7.04 & 7.46 & 7.43 & 7.04 & 7.56 & 7.69 & 7.41 & 7.06 \\
\hline & SD & - & - & - & - & - & - & - & - & - & - \\
\hline & $\mathrm{Cv}$ & - & - & - & - & - & - & - & - & - & - \\
\hline \multirow{6}{*}{ Conductivity } & $\overline{\mathbf{x}}$ & 446.82 & 767.83 & 1110.63 & 646.00 & 374.56 & 345.31 & 638.90 & 638.74 & 450.60 & 572.73 \\
\hline & $\mathrm{Me}$ & 447.70 & 763.40 & 1093.00 & 635.60 & 366.50 & 338.20 & 640.30 & 638.80 & 450.60 & 531.00 \\
\hline & Min & 196.1 & 372.8 & 932.7 & 619.1 & 283.0 & 317.3 & 612.3 & 578.2 & 430.8 & 496.3 \\
\hline & Max & 651.7 & 987.6 & 1305.0 & 696.3 & 493.6 & 404.2 & 662.0 & 696.9 & 473.8 & 729.7 \\
\hline & SD & 112.29 & 172.72 & 108.03 & 24.46 & 58.02 & 29.06 & 13.11 & 34.15 & 12.78 & 78.56 \\
\hline & $\mathrm{Cv}$ & 25.13 & 22.49 & 9.73 & 3.79 & 15.49 & 8.42 & 2.05 & 5.35 & 2.84 & 13.72 \\
\hline \multirow{6}{*}{$\begin{array}{l}\text { Ammonia } \\
{\left[\mathrm{mg}^{2} \mathrm{dm}^{3}\right]}\end{array}$} & $\overline{\mathbf{x}}$ & 0.089 & 0.119 & 0.098 & 0.134 & 0.026 & 0.062 & 0.023 & 0.191 & 0.027 & 0.441 \\
\hline & $\mathrm{Me}$ & 0.010 & 0.100 & 0.100 & 0.130 & 0.010 & 0.010 & 0.010 & 0.020 & 0.010 & 0.300 \\
\hline & Min & 0.010 & 0.010 & 0.010 & 0.020 & 0.010 & 0.010 & 0.010 & 0.010 & 0.010 & 0.010 \\
\hline & Max & 0.530 & 0.340 & 0.190 & 0.290 & 0.100 & 0.380 & 0.100 & 1.320 & 0.100 & 1.320 \\
\hline & SD & 0.16 & 0.10 & 0.08 & 0.08 & 0.03 & 0.12 & 0.03 & 0.40 & 0.03 & 0.45 \\
\hline & $\mathrm{Cv}$ & 180.81 & 83.03 & 77.11 & 61.95 & 109.30 & 186.01 & 119.52 & 210.89 & 119.90 & 101.60 \\
\hline \multirow{6}{*}{$\begin{array}{l}\text { Nitrates } \\
{\left[\mathrm{mg} / \mathrm{dm}^{3}\right]}\end{array}$} & $\overline{\mathbf{x}}$ & 1.68 & 0.91 & 20.80 & 0.73 & 14.66 & 4.86 & 21.12 & 10.74 & 17.19 & 17.46 \\
\hline & $\mathrm{Me}$ & 0.70 & 0.80 & 20.00 & 0.20 & 13.20 & 3.50 & 18.10 & 9.90 & 17.20 & 16.20 \\
\hline & Min & 0.10 & 0.10 & 9.00 & 0.10 & 0.10 & 1.00 & 6.60 & 4.40 & 5.30 & 7.60 \\
\hline & $\operatorname{Max}$ & 5.40 & 2.00 & 33.00 & 2.30 & 32.10 & 11.00 & 38.10 & 17.50 & 22.20 & 30.30 \\
\hline & SD & 1.83 & 0.67 & 7.84 & 0.76 & 10.23 & 3.20 & 9.82 & 5.03 & 4.97 & 7.59 \\
\hline & $\mathrm{Cv}$ & 108.88 & 73.98 & 37.68 & 103.45 & 69.89 & 65.89 & 46.50 & 46.86 & 28.89 & 43.50 \\
\hline \multirow{6}{*}{$\begin{array}{l}\text { Nitrites } \\
{\left[\mathrm{mg} / \mathrm{dm}^{3}\right]}\end{array}$} & $\overline{\mathbf{x}}$ & 0.012 & 0.047 & 0.066 & 0.025 & 0.086 & 0.046 & 0.055 & 0.207 & 0.035 & 0.249 \\
\hline & $\mathrm{Me}$ & 0.006 & 0.051 & 0.045 & 0.017 & 0.008 & 0.017 & 0.025 & 0.037 & 0.006 & 0.151 \\
\hline & Min & 0.002 & 0.010 & 0.010 & 0.005 & 0.005 & 0.005 & 0.002 & 0.004 & 0.002 & 0.057 \\
\hline & Max & 0.030 & 0.098 & 0.178 & 0.094 & 0.359 & 0.163 & 0.182 & 0.942 & 0.263 & 0.788 \\
\hline & SD & 0.01 & 0.03 & 0.05 & 0.03 & 0.13 & 0.05 & 0.06 & 0.29 & 0.08 & 0.22 \\
\hline & $\mathrm{Cv}$ & 80.70 & 55.62 & 75.91 & 107.16 & 147.93 & 114.91 & 110.52 & 139.90 & 231.28 & 86.34 \\
\hline \multirow{6}{*}{$\begin{array}{l}\text { Chlorides } \\
{\left[\mathrm{mg} / \mathrm{dm}^{3}\right]}\end{array}$} & $\overline{\mathbf{x}}$ & 9.57 & 37.56 & 67.07 & 36.34 & 8.39 & 9.74 & 11.01 & 17.90 & 16.64 & 23.50 \\
\hline & $\mathrm{Me}$ & 5.00 & 40.00 & 67.00 & 38.00 & 8.00 & 11.00 & 11.00 & 19.00 & 17.00 & 21.00 \\
\hline & Min & 1.20 & 2.80 & 48.00 & 20.40 & 2.80 & 5.00 & 7.40 & 12.10 & 10.60 & 12.40 \\
\hline & $\operatorname{Max}$ & 30.90 & 52.00 & 82.00 & 65.00 & 16.00 & 13.00 & 14.00 & 26.00 & 22.00 & 40.00 \\
\hline & SD & 8.86 & 14.66 & 12.69 & 12.98 & 4.20 & 3.06 & 2.08 & 4.47 & 3.81 & 7.59 \\
\hline & $\mathrm{Cv}$ & 92.62 & 39.04 & 18.92 & 35.72 & 50.04 & 31.37 & 18.87 & 24.97 & 22.88 & 32.30 \\
\hline & $\overline{\mathbf{x}}$ & 21.89 & 79.00 & 97.89 & 70.61 & 22.67 & 59.22 & 48.00 & 51.89 & 42.56 & 53.11 \\
\hline & $\mathrm{Me}$ & 15.00 & 83.00 & 99.00 & 76.00 & 15.00 & 61.00 & 53.00 & 20.00 & 33.00 & 38.00 \\
\hline sulrates & Min & 11.00 & 14.00 & 84.00 & 7.50 & 10.00 & 16.00 & 15.00 & 10.00 & 14.00 & 16.00 \\
\hline$\left[\mathrm{mg} / \mathrm{dm}^{3}\right]$ & $\operatorname{Max}$ & 67.00 & 112.00 & 111.00 & 90.00 & 66.00 & 81.00 & 74.00 & 192.00 & 170.00 & 177.00 \\
\hline & SD & 16.44 & 26.76 & 8.03 & 23.06 & 17.40 & 16.82 & 21.52 & 58.53 & 45.85 & 46.55 \\
\hline & $\mathrm{Cv}$ & 75.08 & 33.87 & 8.21 & 32.65 & 76.75 & 28.41 & 44.82 & 112.80 & 107.74 & 87.65 \\
\hline & $\overline{\mathbf{x}}$ & 0.53 & 4.50 & 0.02 & 2.73 & 0.10 & 0.22 & 0.08 & 0.06 & 0.07 & 0.33 \\
\hline & $\mathrm{Me}$ & 0.01 & 3.15 & 0.01 & 2.80 & 0.01 & 0.26 & 0.01 & 0.01 & 0.01 & 0.01 \\
\hline & Min & 0.01 & 0.01 & 0.01 & 1.33 & 0.01 & 0.01 & 0.01 & 0.01 & 0.01 & 0.01 \\
\hline$\left[\mathrm{mg} / \mathrm{dm}^{3}\right]$ & $\operatorname{Max}$ & 4.39 & 17.00 & 0.09 & 5.64 & 0.36 & 0.50 & 0.32 & 0.25 & 0.31 & 2.00 \\
\hline & SD & 1.37 & 4.93 & 0.03 & 1.28 & 0.13 & 0.15 & 0.12 & 0.08 & 0.10 & 0.62 \\
\hline & $\mathrm{Cv}$ & 259.70 & 109.45 & 100.41 & 46.83 & 130.68 & 70.03 & 148.72 & 131.17 & 139.04 & 190.67 \\
\hline & $\overline{\mathbf{x}}$ & 0.08 & 0.73 & 0.10 & 0.44 & 0.06 & 0.09 & 0.04 & 0.14 & 0.03 & 0.11 \\
\hline & $\mathrm{Me}$ & 0.02 & 0.75 & 0.07 & 0.36 & 0.05 & 0.07 & 0.03 & 0.10 & 0.01 & 0.07 \\
\hline & Min & 0.01 & 0.10 & 0.02 & 0.28 & 0.01 & 0.03 & 0.01 & 0.01 & 0.01 & 0.01 \\
\hline$\left[\mathrm{mg} / \mathrm{dm}^{3}\right]$ & $\operatorname{Max}$ & 0.39 & 1.26 & 0.33 & 0.85 & 0.15 & 0.17 & 0.09 & 0.31 & 0.10 & 0.24 \\
\hline & SD & 0.12 & 0.35 & 0.10 & 0.17 & 0.05 & 0.04 & 0.03 & 0.10 & 0.03 & 0.08 \\
\hline & $\mathrm{CV}$ & 154.45 & 47.87 & 92.94 & 38.61 & 77.38 & 49.62 & 72.73 & 69.18 & 97.90 & 72.50 \\
\hline & $\overline{\mathbf{x}}$ & 165.34 & 360.55 & 317.04 & 300.23 & 116.89 & 118.47 & 106.60 & 267.40 & 143.39 & 192.24 \\
\hline & $\mathrm{Me}$ & 176.22 & 364.90 & 304.38 & 295.48 & 113.92 & 113.92 & 108.58 & 256.32 & 149.52 & 199.36 \\
\hline Tot & Min & 48.06 & 176.22 & 274.12 & 272.34 & 76.54 & 90.78 & 89.00 & 231.40 & 126.38 & 163.76 \\
\hline$\left[\mathrm{ma} / \mathrm{dm}^{3}\right]$ & $\operatorname{Max}$ & 194.02 & 475.26 & 361.34 & 325.74 & 147.74 & 153.08 & 115.70 & 315.06 & 156.64 & 218.94 \\
\hline & SD & 42.14 & 83.25 & 30.073 & 18.84 & 19.43 & 16.12 & 8.16 & 30.09 & 11.14 & 17.54 \\
\hline & $\mathrm{Cv}$ & 25.48 & 23.09 & 9.49 & 6.28 & 16.62 & 13.61 & 7.65 & 11.25 & 7.77 & 9.13 \\
\hline
\end{tabular}


Table 8. Quality of groundwater from wells in Dębowa Kłoda commune $(n=9)$

\begin{tabular}{|c|c|c|c|c|c|c|c|c|c|c|c|}
\hline \multirow{2}{*}{ Parameters } & \multicolumn{11}{|c|}{ Number of well } \\
\hline & & 1 & 2 & 3 & 4 & 5 & 6 & 7 & 8 & 9 & 10 \\
\hline \multirow{6}{*}{$\begin{array}{l}\text { Depth of the } \\
\text { water table }\end{array}$} & $\overline{\mathbf{x}}$ & 2.01 & 2.53 & 1.53 & 1.94 & 1.73 & 1.84 & 1.73 & 1.94 & 1.89 & 2.08 \\
\hline & $\mathrm{Me}$ & 2.00 & 2.50 & 1.60 & 2.00 & 1.60 & 1.90 & 1.80 & 2.10 & 2.00 & 2.10 \\
\hline & Min & 1.60 & 2.10 & 0.90 & 1.60 & 1.50 & 1.50 & 1.00 & 1.20 & 1.30 & 1.70 \\
\hline & Max & 2.30 & 2.90 & 1.80 & 2.20 & 2.00 & 2.10 & 2.70 & 2.40 & 2.10 & 2.40 \\
\hline & SD & 0.22 & 0.23 & 0.29 & 0.22 & 0.19 & 0.21 & 0.48 & 0.35 & 0.26 & 0.23 \\
\hline & $\mathrm{Cv}$ & 11.11 & 9.12 & 19.20 & 11.40 & 11.21 & 11.17 & 27.92 & 17.00 & 13.00 & 11.06 \\
\hline \multirow{6}{*}{$\mathrm{pH}$} & $\overline{\mathrm{x}}$ & - & - & - & - & - & - & - & - & - & - \\
\hline & $\mathrm{Me}$ & - & - & - & - & - & - & - & - & - & - \\
\hline & Min & 7.38 & 6.50 & 7.36 & 6.85 & 7.06 & 7.26 & 6.54 & 6.90 & 6.67 & 7.28 \\
\hline & Max & 7.97 & 6.77 & 7.87 & 7.61 & 7.83 & 7.76 & 6.94 & 7.17 & 7.28 & 7.76 \\
\hline & SD & - & - & - & - & - & - & - & - & - & - \\
\hline & $\mathrm{Cv}$ & - & - & - & - & - & - & - & - & - & - \\
\hline \multirow{6}{*}{$\begin{array}{l}\text { Conductivity } \\
\text { [ }[\mu \mathrm{s} / \mathrm{cm}]\end{array}$} & $\overline{\mathbf{x}}$ & 1025.84 & 443.03 & 572.24 & 820.09 & 297.73 & 685.47 & 551.71 & 468.07 & 530.50 & 702.51 \\
\hline & $\mathrm{Me}$ & 1022.00 & 432.60 & 575.50 & 827.60 & 301.80 & 680.10 & 522.05 & 463.90 & 574.40 & 746.20 \\
\hline & Min & 962.3 & 407.10 & 531.9 & 730.3 & 273.8 & 548.5 & 480.2 & 378.2 & 380.0 & 439.1 \\
\hline & Max & 1090.0 & 502.4 & 591.3 & 920.6 & 329.3 & 812.9 & 660.5 & 582.0 & 598.5 & 918.9 \\
\hline & SD & 44.08 & 30.83 & 19.34 & 63.71 & 14.97 & 83.73 & 69.77 & 60.25 & 74.42 & 181.08 \\
\hline & $\mathrm{Cv}$ & 4.30 & 6.96 & 3.38 & 7.77 & 5.03 & 12.22 & 12.65 & 12.87 & 14.03 & 25.78 \\
\hline \multirow{6}{*}{$\begin{array}{l}\text { Ammonia } \\
{\left[\mathrm{mg} / \mathrm{dm}^{3}\right]}\end{array}$} & $\overline{\mathrm{x}}$ & 0.028 & 0.024 & 0.023 & 0.034 & 0.057 & 0.116 & 0.046 & 0.081 & 0.039 & 0.020 \\
\hline & $\mathrm{Me}$ & 0.010 & 0.010 & 0.010 & 0.010 & 0.010 & 0.010 & 0.030 & 0.010 & 0.010 & 0.010 \\
\hline & Min & 0.010 & 0.010 & 0.010 & 0.010 & 0.010 & 0.010 & 0.010 & 0.010 & 0.010 & 0.010 \\
\hline & Max & 0.080 & 0.090 & 0.080 & 0.140 & 0.390 & 0.470 & 0.130 & 0.490 & 0.140 & 0.080 \\
\hline & SD & 0.03 & 0.03 & 0.02 & 0.04 & 0.12 & 0.18 & 0.04 & 0.15 & 0.05 & 0.02 \\
\hline & $\mathrm{Cv}$ & 97.16 & 100.41 & 94.76 & 117.82 & 208.64 & 155.72 & 85.08 & 184.84 & 116.55 & 108.01 \\
\hline \multirow{6}{*}{$\begin{array}{l}\text { Nitrates } \\
{\left[\mathrm{mg} / \mathrm{dm}^{3}\right]}\end{array}$} & $\overline{\mathbf{x}}$ & 19.37 & 17.17 & 15.02 & 17.60 & 4.22 & 3.53 & 19.06 & 8.42 & 12.32 & 17.42 \\
\hline & $\mathrm{Me}$ & 17.30 & 15.40 & 12.80 & 22.10 & 3.30 & 3.50 & 17.80 & 7.40 & 9.30 & 14.60 \\
\hline & Min & 5.70 & 3.70 & 8.00 & 0.02 & 1.40 & 0.01 & 6.60 & 3.10 & 5.20 & 5.50 \\
\hline & Max & 27.00 & 27.80 & 35.10 & 25.50 & 8.40 & 8.80 & 35.40 & 17.80 & 24.70 & 33.60 \\
\hline & SD & 6.54 & 7.91 & 7.41 & 8.53 & 2.35 & 2.45 & 9.20 & 4.85 & 6.63 & 8.88 \\
\hline & $\mathrm{Cv}$ & 33.74 & 46.06 & 49.34 & 48.46 & 55.68 & 69.44 & 48.24 & 57.60 & 53.84 & 50.98 \\
\hline \multirow{6}{*}{$\begin{array}{l}\text { Nitrites } \\
{\left[\mathrm{mg} / \mathrm{dm}^{3}\right]}\end{array}$} & $\overline{\mathbf{x}}$ & 0.107 & 0.036 & 0.075 & 0.086 & 0.021 & 0.406 & 0.283 & 0.042 & 0.044 & 0.138 \\
\hline & $\mathrm{Me}$ & 0.077 & 0.015 & 0.070 & 0.017 & 0.020 & 0.013 & 0.079 & 0.022 & 0.044 & 0.159 \\
\hline & Min & 0.002 & 0.002 & 0.002 & 0.002 & 0.001 & 0.001 & 0.002 & 0.002 & 0.003 & 0.001 \\
\hline & Max & 0.390 & 0.100 & 0.249 & 0.504 & 0.071 & 3.400 & 0.842 & 0.196 & 0.150 & 0.491 \\
\hline & SD & 0.12 & 0.04 & 0.07 & 0.15 & 0.02 & 1.06 & 0.34 & 0.06 & 0.04 & 0.15 \\
\hline & $\mathrm{CV}$ & 112.88 & 107.30 & 97.18 & 177.02 & 98.59 & 261.28 & 119.16 & 134.74 & 95.99 & 108.81 \\
\hline \multirow{6}{*}{$\begin{array}{l}\text { Chlorides } \\
{\left[\mathrm{mg} / \mathrm{dm}^{3}\right]}\end{array}$} & $\overline{\mathbf{x}}$ & 25.63 & 8.03 & 22.67 & 17.93 & 2.52 & 12.14 & 15.96 & 3.29 & 24.49 & 20.97 \\
\hline & $\mathrm{Me}$ & 24.00 & 8.00 & 22.00 & 18.40 & 2.00 & 12.00 & 15.00 & 3.00 & 23.00 & 23.00 \\
\hline & Min & 14.00 & 6.00 & 20.00 & 11.00 & 1.00 & 7.00 & 12.00 & 1.00 & 9.00 & 3.00 \\
\hline & Max & 41.00 & 10.00 & 27.00 & 23.00 & 5.00 & 17.00 & 21.00 & 6.00 & 37.00 & 45.00 \\
\hline & SD & 7.02 & 1.16 & 2.67 & 3.45 & 1.06 & 2.76 & 2.86 & 1.37 & 7.47 & 15.23 \\
\hline & $\mathrm{CV}$ & 27.39 & 14.42 & 11.77 & 19.24 & 41.87 & 22.68 & 17.90 & 41.55 & 30.50 & 72.62 \\
\hline & $\overline{\mathbf{x}}$ & 96.67 & 50.11 & 65.33 & 17.11 & 24.33 & 121.89 & 13.63 & 15.56 & 65.00 & 50.22 \\
\hline & $\mathrm{Me}$ & 102.00 & 50.00 & 71.00 & 15.00 & 17.00 & 125.00 & 14.00 & 16.00 & 88.00 & 65.00 \\
\hline Sulfates & Min & 14.00 & 44.00 & 18.00 & 14.00 & 15.00 & 90.00 & 11.00 & 13.00 & 17.00 & 12.00 \\
\hline$\left[\mathrm{maldm} \mathrm{d}^{3}\right.$ & $\operatorname{Max}$ & 156.00 & 58.00 & 78.00 & 37.00 & 87.00 & 149.00 & 15.00 & 17.00 & 107.00 & 91.00 \\
\hline [mig/uin'] & SD & 47.36 & 4.20 & 17.38 & 7.05 & 22.21 & 20.57 & 1.32 & 1.50 & 35.90 & 32.78 \\
\hline & $\mathrm{Cv}$ & 48.99 & 8.39 & 26.60 & 41.18 & 91.26 & 16.87 & 9.67 & 9.64 & 55.23 & 65.26 \\
\hline & $\overline{\mathbf{x}}$ & 0.07 & 0.11 & 0.14 & 0.05 & 0.25 & 0.04 & 0.16 & 0.18 & 0.24 & 0.07 \\
\hline & $\mathrm{Me}$ & 0.05 & 0.04 & 0.13 & 0.05 & 0.24 & 0.01 & 0.11 & 0.15 & 0.17 & 0.06 \\
\hline & Min & 0.01 & 0.01 & 0.02 & 0.01 & 0.11 & 0.01 & 0.03 & 0.01 & 0.08 & 0.01 \\
\hline$\left[\mathrm{mg} / \mathrm{dm}^{3}\right]$ & $\operatorname{Max}$ & 0.25 & 0.40 & 0.25 & 0.09 & 0.41 & 0.13 & 0.46 & 0.39 & 0.51 & 0.20 \\
\hline [mg/arm'] & SD & 0.07 & 0.15 & 0.07 & 0.030 & 0.10 & 0.04 & 0.13 & 0.10 & 0.15 & 0.06 \\
\hline & $\mathrm{CV}$ & 108.37 & 138.09 & 51.86 & 56.49 & 38.43 & 105.24 & 83.48 & 54.12 & 60.62 & 85.28 \\
\hline & $\overline{\mathbf{x}}$ & 0.09 & 0.04 & 0.16 & 0.06 & 0.13 & 0.10 & 0.15 & 0.15 & 0.19 & 0.08 \\
\hline & $\mathrm{Me}$ & 0.07 & 0.01 & 0.12 & 0.04 & 0.10 & 0.06 & 0.15 & 0.13 & 0.15 & 0.04 \\
\hline Mianganese & Min & 0.01 & 0.01 & 0.07 & 0.03 & 0.04 & 0.01 & 0.04 & 0.10 & 0.06 & 0.01 \\
\hline & $\operatorname{Max}$ & 0.22 & 0.19 & 0.46 & 0.13 & 0.24 & 0.34 & 0.31 & 0.30 & 0.37 & 0.26 \\
\hline$\left[\mathrm{mg}^{2} \mathrm{dm}^{3}\right]$ & SD & 0.06 & 0.06 & 0.12 & 0.03 & 0.06 & 0.10 & 0.09 & 0.06 & 0.11 & 0.09 \\
\hline & $\mathrm{CV}$ & 70.47 & 145.94 & 72.21 & 51.26 & 46.73 & 100.27 & 58.08 & 39.97 & 55.79 & 116.99 \\
\hline & $\overline{\mathbf{x}}$ & 253.75 & 187.49 & 235.75 & 241.68 & 150.90 & 274.52 & 252.76 & 130.73 & 138.05 & 269.57 \\
\hline & $\mathrm{Me}$ & 277.68 & 170.88 & 217.16 & 258.10 & 145.96 & 279.46 & 242.08 & 144.18 & 138.84 & 261.66 \\
\hline Total hardness & Min & 147.74 & 137.06 & 197.58 & 64.08 & 117.48 & 213.60 & 172.66 & 78.32 & 96.12 & 206.48 \\
\hline$[\mathrm{mg} / \mathrm{d}$ & $\operatorname{Max}$ & 290.14 & 243.86 & 402.28 & 311.50 & 176.22 & 311.50 & 336.42 & 167.32 & 169.10 & 320.40 \\
\hline [ ing/unim] & SD & 42.40 & 36.75 & 59.41 & 71.63 & 17.19 & 34.25 & 61.33 & 30.79 & 19.27 & 38.31 \\
\hline & $\mathrm{CV}$ & 16.70 & 19.60 & 25.20 & 29.64 & 11.39 & 12.48 & 24.26 & 23.55 & 13.96 & 14.21 \\
\hline
\end{tabular}


Table 9. Quality of groundwater from wells in Urszulin commune $(n=9)$

\begin{tabular}{|c|c|c|c|c|c|c|c|c|c|c|c|}
\hline \multirow{2}{*}{ Parameters } & \multicolumn{11}{|c|}{ Number of well } \\
\hline & & 1 & 2 & 3 & 4 & 5 & 6 & 7 & 8 & 9 & 10 \\
\hline \multirow{6}{*}{$\begin{array}{l}\text { Depth of the } \\
\text { water table }\end{array}$} & $\overline{\mathrm{x}}$ & 2.33 & 2.33 & 2.76 & 2.62 & 2.13 & 2.39 & 2.43 & 2.52 & 2.26 & 2.29 \\
\hline & $\mathrm{Me}$ & 2.30 & 2.50 & 3.00 & 2.60 & 2.50 & 2.60 & 2.70 & 2.80 & 2.50 & 2.40 \\
\hline & Min & 1.60 & 1.60 & 1.70 & 1.20 & 0.70 & 1.70 & 1.60 & 1.80 & 1.50 & 1.00 \\
\hline & $\operatorname{Max}$ & 2.90 & 3.00 & 3.40 & 3.90 & 2.70 & 2.80 & 3.00 & 3.00 & 2.90 & 3.00 \\
\hline & SD & 0.45 & 0.52 & 0.64 & 0.75 & 0.66 & 0.43 & 0.57 & 0.48 & 0.47 & 0.58 \\
\hline & $\mathrm{Cv}$ & 19.44 & 22.32 & 23.09 & 28.70 & 31.09 & 17.92 & 23.49 & 19.04 & 20.70 & 25.35 \\
\hline \multirow{6}{*}{$\mathrm{pH}$} & $\overline{\mathrm{x}}$ & - & - & - & - & - & - & - & - & - & - \\
\hline & $\mathrm{Me}$ & - & - & - & - & - & - & - & - & - & - \\
\hline & Min & 7.11 & 7.11 & 7.43 & 6.23 & 6.85 & 7.09 & 7.09 & 7.35 & 7.10 & 7.07 \\
\hline & $\operatorname{Max}$ & 7.62 & 7.49 & 7.75 & 7.20 & 7.50 & 7.42 & 7.58 & 7.77 & 7.58 & 7.45 \\
\hline & SD & - & - & - & - & - & - & - & - & - & - \\
\hline & $\mathrm{Cv}$ & - & - & - & - & - & - & - & - & - & - \\
\hline \multirow{6}{*}{ Conductivity } & $\overline{\mathbf{x}}$ & 260.34 & 778.84 & 1113.44 & 981.32 & 965.53 & 1011.79 & 400.79 & 1055.64 & 722.63 & 835.46 \\
\hline & $\mathrm{Me}$ & 253.65 & 777.50 & 1116.00 & 1059.00 & 910.20 & 1147.00 & 417.80 & 1049.00 & 740.00 & 836.10 \\
\hline & Min & 233.2 & 705.2 & 1064.0 & 495.7 & 895.2 & 621.9 & 319.0 & 980.8 & 588.2 & 769.4 \\
\hline & Max & 300.5 & 841.0 & 1161.0 & 1083.0 & 1113.0 & 1248.0 & 441.2 & 1118.0 & 775.4 & 931.8 \\
\hline & SD & 20.29 & 47.47 & 24.63 & 177.54 & 81.87 & 245.07 & 36.85 & 42.76 & 59.30 & 41.66 \\
\hline & $\mathrm{Cv}$ & 7.80 & 6.10 & 2.21 & 18.09 & 8.48 & 24.22 & 9.20 & 4.05 & 8.21 & 4.99 \\
\hline \multirow{6}{*}{$\begin{array}{l}\text { Ammonia } \\
{\left[\mathrm{mg} / \mathrm{dm}^{3}\right]}\end{array}$} & $\overline{\mathbf{x}}$ & 0.094 & 0.021 & 0.010 & 0.072 & 0.042 & 0.052 & 0.099 & 1.043 & 0.118 & 0.017 \\
\hline & $\mathrm{Me}$ & 0.080 & 0.010 & 0.010 & 0.010 & 0.010 & 0.010 & 0.020 & 0.220 & 0.020 & 0.010 \\
\hline & Min & 0.010 & 0.010 & 0.010 & 0.010 & 0.010 & 0.010 & 0.010 & 0.010 & 0.010 & 0.010 \\
\hline & Max & 0.220 & 0.110 & 0.010 & 0.210 & 0.130 & 0.160 & 0.450 & 6.480 & 0.860 & 0.070 \\
\hline & SD & 0.08 & 0.03 & 0.00 & 0.08 & 0.04 & 0.06 & 0.15 & 1.97 & 0.26 & 0.02 \\
\hline & $\mathrm{Cv}$ & 84.82 & 148.87 & 0.00 & 113.95 & 99.72 & 113.39 & 149.04 & 189.03 & 223.31 & 113.14 \\
\hline \multirow{6}{*}{$\begin{array}{l}\text { Nitrates } \\
{\left[\mathrm{mg} / \mathrm{dm}^{3}\right]}\end{array}$} & $\overline{\mathbf{x}}$ & 1.19 & 4.81 & 10.41 & 14.38 & 12.16 & 22.51 & 18.71 & 17.74 & 16.79 & 18.04 \\
\hline & $\mathrm{Me}$ & 0.60 & 3.90 & 6.50 & 16.00 & 7.80 & 17.30 & 17.20 & 17.20 & 17.20 & 19.60 \\
\hline & Min & 0.10 & 1.70 & 0.03 & 6.20 & 1.70 & 5.30 & 6.20 & 5.60 & 5.70 & 0.20 \\
\hline & Max & 5.50 & 10.80 & 27.80 & 22.70 & 29.90 & 36.20 & 33.00 & 24.90 & 31.50 & 34.20 \\
\hline & SD & 1.68 & 3.05 & 8.40 & 5.96 & 9.16 & 9.67 & 9.52 & 5.90 & 7.84 & 8.71 \\
\hline & $\mathrm{Cv}$ & 141.19 & 63.38 & 80.68 & 41.45 & 75.32 & 42.98 & 50.88 & 33.25 & 46.67 & 48.28 \\
\hline \multirow{6}{*}{$\begin{array}{l}\text { Nitrites } \\
{\left[\mathrm{mg} / \mathrm{dm}^{3}\right]}\end{array}$} & $\overline{\mathbf{x}}$ & 0.055 & 0.030 & 0.060 & 0.104 & 0.060 & 0.145 & 0.048 & 0.269 & 0.042 & 0.023 \\
\hline & $\mathrm{Me}$ & 0.041 & 0.015 & 0.056 & 0.101 & 0.033 & 0.094 & 0.034 & 0.224 & 0.024 & 0.013 \\
\hline & Min & 0.017 & 0.002 & 0.009 & 0.005 & 0.005 & 0.005 & 0.008 & 0.029 & 0.005 & 0.005 \\
\hline & Max & 0.144 & 0.137 & 0.133 & 0.224 & 0.191 & 0.584 & 0.119 & 0.780 & 0.108 & 0.070 \\
\hline & SD & 0.04 & 0.04 & 0.04 & 0.08 & 0.06 & 0.17 & 0.04 & 0.22 & 0.04 & 0.02 \\
\hline & $\mathrm{Cv}$ & 76.00 & 134.79 & 73.74 & 75.32 & 106.27 & 117.78 & 76.35 & 82.13 & 93.53 & 90.79 \\
\hline \multirow{6}{*}{$\begin{array}{l}\text { Chlorides } \\
{\left[\mathrm{mg} / \mathrm{dm}^{3}\right]}\end{array}$} & $\overline{\mathbf{x}}$ & 4.06 & 9.19 & 13.68 & 12.31 & 15.64 & 21.44 & 5.58 & 24.08 & 5.78 & 13.47 \\
\hline & $\mathrm{Me}$ & 2.50 & 10.00 & 16.00 & 9.00 & 18.00 & 25.50 & 7.00 & 31.00 & 8.00 & 14.00 \\
\hline & Min & 0.20 & 1.00 & 1.00 & 1.00 & 1.00 & 0.50 & 1.00 & 1.00 & 0.20 & 1.00 \\
\hline & Max & 16.00 & 14.00 & 19.00 & 30.00 & 23.00 & 38.00 & 9.00 & 38.00 & 10.00 & 20.70 \\
\hline & SD & 4.75 & 3.78 & 5.31 & 9.14 & 7.41 & 15.15 & 2.55 & 11.29 & 3.56 & 5.07 \\
\hline & $\mathrm{Cv}$ & 116.99 & 41.18 & 38.85 & 74.22 & 47.37 & 70.63 & 45.64 & 46.90 & 61.61 & 37.67 \\
\hline & $\overline{\mathbf{x}}$ & 15.88 & 25.22 & 95.67 & 125.22 & 102.00 & 71.22 & 17.78 & 47.67 & 33.22 & 14.78 \\
\hline & $\mathrm{Me}$ & 15.00 & 15.00 & 108.00 & 120.00 & 98.00 & 101.00 & 15.00 & 17.00 & 36.00 & 14.00 \\
\hline Sulrates & Min & 15.0 & 14.0 & 57.0 & 73.0 & 92.0 & 15.0 & 15.0 & 12.0 & 14.0 & 11.0 \\
\hline$\left[\mathrm{mg} / \mathrm{dm}^{3}\right]$ & Max & 22.0 & 65.0 & 124.0 & 191.0 & 121.0 & 120.0 & 26.0 & 112.0 & 57.0 & 22.0 \\
\hline & SD & 2.32 & 18.35 & 24.47 & 34.15 & 10.30 & 45.75 & 4.08 & 39.96 & 17.33 & 2.78 \\
\hline & $\mathrm{Cv}$ & 14.58 & 72.77 & 25.58 & 27.27 & 10.09 & 64.23 & 22.93 & 83.83 & 52.17 & 18.81 \\
\hline & $\overline{\mathbf{x}}$ & 0.13 & 0.05 & 0.05 & 0.36 & 0.09 & 0.09 & 0.27 & 0.05 & 0.07 & 0.05 \\
\hline & $\mathrm{Me}$ & 0.13 & 0.03 & 0.06 & 0.12 & 0.07 & 0.10 & 0.12 & 0.05 & 0.06 & 0.01 \\
\hline & Min & 0.01 & 0.01 & 0.01 & 0.01 & 0.01 & 0.01 & 0.01 & 0.01 & 0.01 & 0.01 \\
\hline$\left[\mathrm{mg}^{2} \mathrm{dm}^{3}\right]$ & Max & 0.41 & 0.13 & 0.11 & 1.81 & 0.26 & 0.20 & 0.91 & 0.12 & 0.21 & 0.33 \\
\hline & SD & 0.13 & 0.04 & 0.04 & 0.54 & 0.08 & 0.06 & 0.34 & 0.04 & 0.07 & 0.10 \\
\hline & $\mathrm{Cv}$ & 97.86 & 81.44 & 76.12 & 148.59 & 88.21 & 70.80 & 124.84 & 73.01 & 100.65 & 180.40 \\
\hline & $\overline{\mathbf{x}}$ & 0.14 & 0.04 & 0.07 & 0.26 & 0.08 & 0.13 & 0.19 & 0.06 & 0.06 & 0.03 \\
\hline & $\mathrm{Me}$ & 0.11 & 0.04 & 0.05 & 0.14 & 0.06 & 0.11 & 0.13 & 0.06 & 0.04 & 0.03 \\
\hline & Min & 0.01 & 0.01 & 0.01 & 0.01 & 0.01 & 0.06 & 0.07 & 0.01 & 0.01 & 0.01 \\
\hline$\left[\mathrm{mg} / \mathrm{dm}^{3}\right]$ & $\operatorname{Max}$ & 0.33 & 0.11 & 0.29 & 1.13 & 0.16 & 0.34 & 0.51 & 0.12 & 0.23 & 0.06 \\
\hline & SD & 0.10 & 0.03 & 0.08 & 0.33 & 0.06 & 0.08 & 0.15 & 0.04 & 0.07 & 0.02 \\
\hline & $\mathrm{Cv}$ & 69.62 & 71.69 & 123.09 & 126.58 & 71.66 & 62.97 & 80.54 & 66.55 & 105.61 & 56.24 \\
\hline & $\overline{\mathbf{x}}$ & 112.59 & 318.82 & 271.35 & 416.12 & 413.95 & 315.65 & 136.86 & 296.86 & 231.80 & 222.90 \\
\hline & $\mathrm{Me}$ & 117.48 & 306.16 & 268.78 & 478.82 & 409.40 & 331.08 & 144.18 & 311.50 & 233.18 & 224.28 \\
\hline & Min & 80.10 & 270.56 & 234.96 & 181.56 & 302.60 & 206.48 & 105.02 & 144.18 & 147.74 & 179.78 \\
\hline$\left[\mathrm{mg} / \mathrm{dm}^{3}\right]$ & Max & 133.50 & 411.18 & 307.94 & 530.44 & 555.36 & 398.72 & 163.76 & 404.06 & 274.12 & 272.34 \\
\hline & SD & 16.21 & 40.70 & 24.81 & 103.82 & 68.42 & 62.48 & 18.94 & 66.18 & 35.55 & 26.24 \\
\hline & $\mathrm{CV}$ & 14.40 & 12.77 & 9.14 & 24.95 & 16.53 & 19.80 & 13.84 & 22.29 & 15.34 & 11.77 \\
\hline
\end{tabular}


of ammonia nitrogen in the water discharged to soil via drainage systems were very high and amounted to $136-157 \mathrm{mg} / \mathrm{dm}^{3}$ (Tables $1-3$ ).

Nitrates. The main reasons for the pollution of groundwater with nitrates are the inappropriate placement of a well, inadequate technical parameters of a well, and migration of nitrogen compounds from agricultural areas [Kiryluk 2011]. In the analyzed well water samples, the mean concentrations of nitrates ranged from 0.73 to $21.12 \mathrm{mg} / \mathrm{dm}^{3}$ in Drelów, from 4.22 to $19.37 \mathrm{mg} / \mathrm{dm}^{3}$ in Dębowa Kłoda, and from 1.19 to $22.51 \mathrm{mg} / \mathrm{dm}^{3}$ in Urszulin (Tables 7-9).

The permissible ammonia content, established in the Regulation of the Minister of Health [2017] for the water intended for human consumption equaling $50 \mathrm{mg} / \mathrm{dm}^{3}$ was not exceeded in the waters from considered wells (Figure 7).

Nitrites. In the analyzed samples of well waters, the mean concentration of nitrites in well waters ranged from 0.012 to $0.249 \mathrm{mg} / \mathrm{dm}^{3}$ in Drelów, from 0.021 to $0.406 \mathrm{mg} / \mathrm{dm}^{3}$ in Dębowa Kłoda, and from 0.023 to $0.269 \mathrm{mg} / \mathrm{dm}^{3}$ in Urszulin (Table 7-9).

The permissible content of nitrites, determined in the Regulation of the Minister of Health [2017] for the water intended for human consumption at a level of $0.5 \mathrm{mg} / \mathrm{dm}^{3}$ was exceeded in the well waters from all three considered communes (Figure 8). Elevated concentrations of nitrites were found in wells no. 8 and 10 in Drelów, wells no. 6 and 7 in Dębowa Kłoda, as well as wells no. 6 and 8 in Urszulin.

Chlorides. In the analyzed samples of well waters, the mean concentrations of chlorides ranged from 8.39 to $67.07 \mathrm{mg} / \mathrm{dm}^{3}$ in Drelów, from 2.52 to $25.63 \mathrm{mg} / \mathrm{dm}^{3}$ in Dębowa Kłoda, as well as from 4.06 to $24.08 \mathrm{mg} / \mathrm{dm}^{3}$ in Urszulin (Tables 7-9). The permissible content of chlorides determined in the Regulation of the Minister of Health [2017] for the water intended for human consumption at a level of $250 \mathrm{mg} / \mathrm{dm}^{3}$ was not exceeded in the investigated well waters (Figure 9).

Sulfates. In the analyzed samples of well waters, the mean concentrations of sulfates ranged from 21.89 to $97.89 \mathrm{mg} / \mathrm{dm}^{3}$ in Drelów, from 13.63 to $121.89 \mathrm{mg} / \mathrm{dm}^{3}$ in Dębowa Kłoda, as well as from 14.78 to $125.22 \mathrm{mg} / \mathrm{dm}^{3}$ in Urszulin (Tables 7-9). Despite a relatively high concentration of sulfates in the water from the considered wells, their permissible content, determined in the Regulation of the Minister of Health [2017] for the water intended for human consumption, equal to $250 \mathrm{mg} / \mathrm{dm}^{3}$, was not exceeded (Figure 10).

Iron. In the analyzed samples of well water, the mean iron concentrations ranged from 0.02
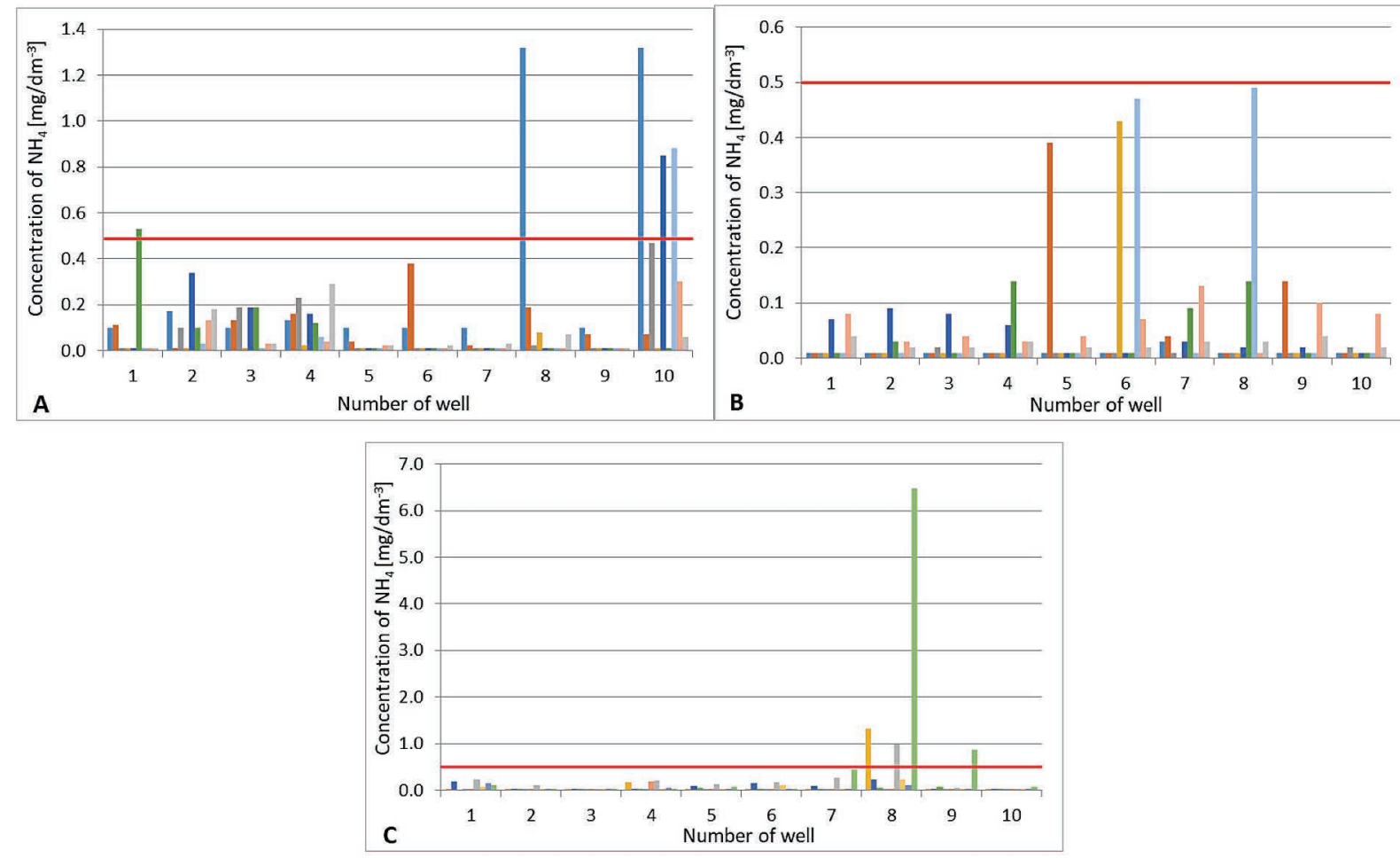

Figure 6. Concentration of ammonia in the well waters (A - Drelów; B - Dębowa Kłoda; C - Urszulin) Notation: continuous red line - Polish requirements for drinking water $\left(0.5 \mathrm{mg} / \mathrm{dm}^{3}\right)$

[Regulation of the Minister of Health 2017] 

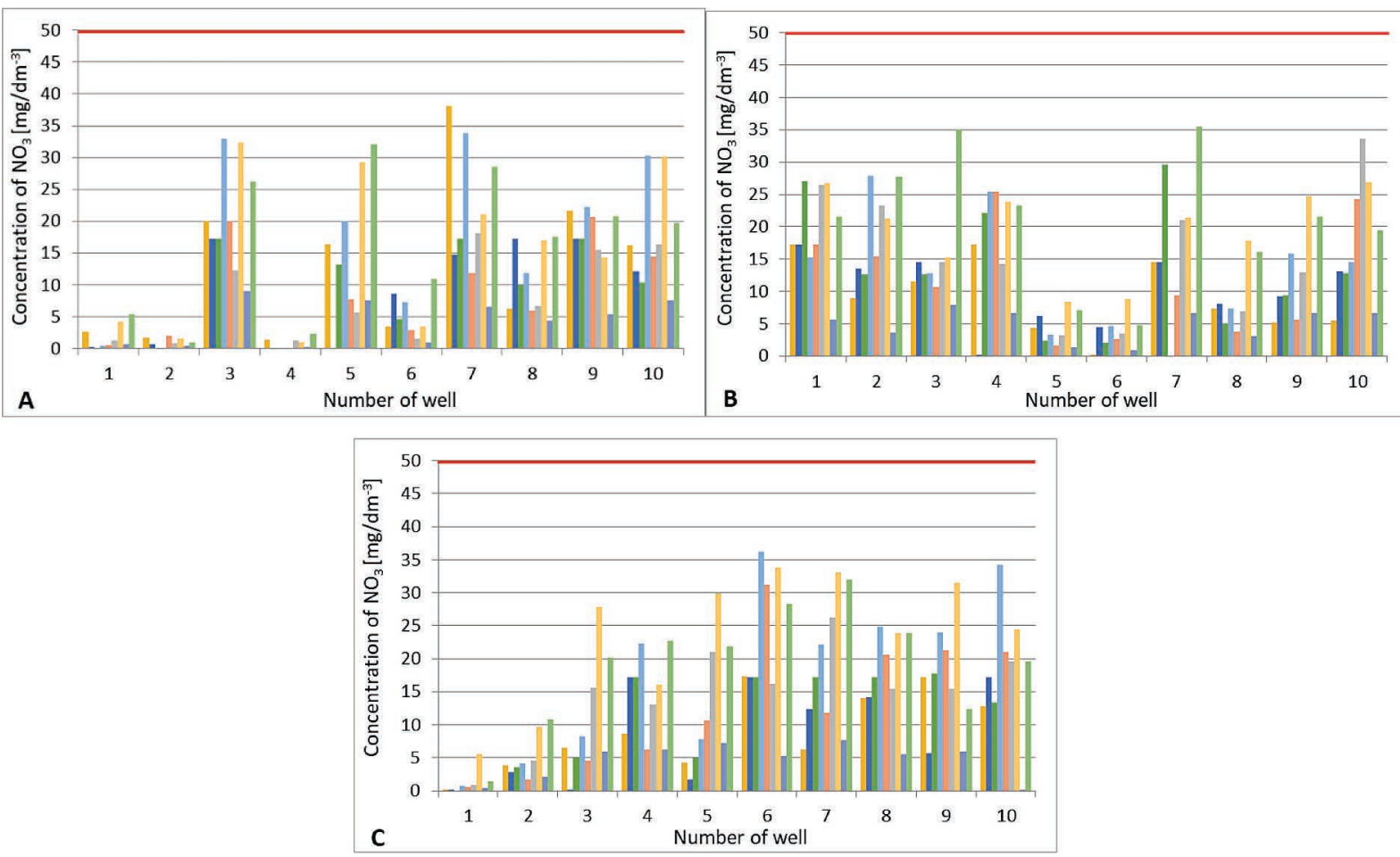

Figure 7. Concentration of nitrates in the well waters (A - Drelów; B - Dębowa Kłoda; C - Urszulin) Notation: continuous red line - Polish requirements for drinking water $\left(50 \mathrm{mg} / \mathrm{dm}^{-3}\right)$

[Regulation of the Minister of Health 2017]
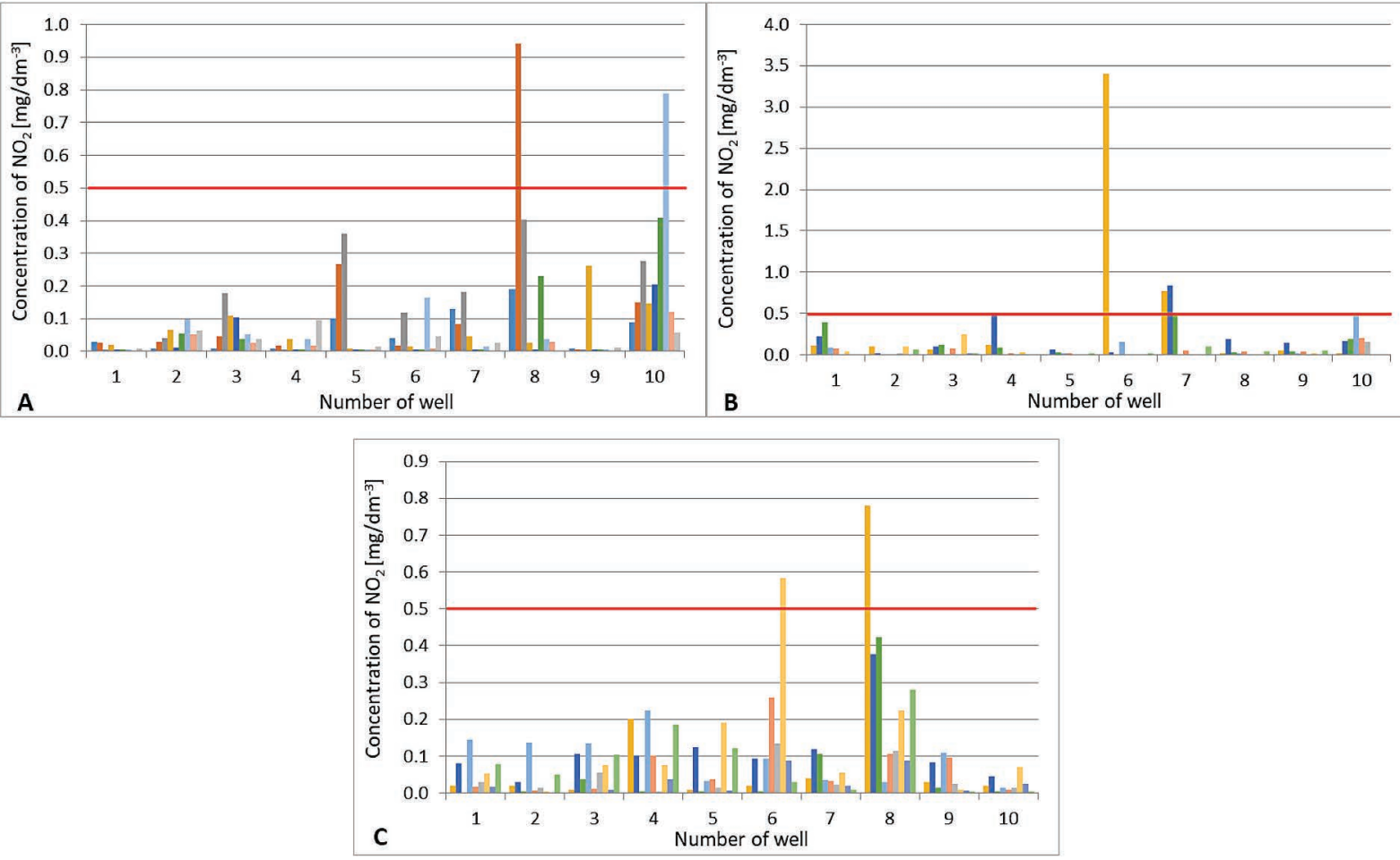

Figure 8. Concentration of nitrites in the well waters (A - Drelów; B - Dębowa Kłoda; C - Urszulin) Notation: continuous red line - Polish requirements for drinking water $\left(0.5 \mathrm{mg} / \mathrm{dm}^{3}\right)$

[Regulation of the Minister of Health 2017]

to $4.50 \mathrm{mg} / \mathrm{dm}^{3}$ in Drelów, from 0.04 to 0.25 in Dębowa Kłoda and from 0.05 to $0.36 \mathrm{mg} /$ $\mathrm{dm}^{3}$ in Urszulin (Tables 7-9). The permissible iron content, determined in the Regulation of the Minister of Health [2017] for the water intended for human consumption at $0.2 \mathrm{mg} / \mathrm{dm}^{3}$, 

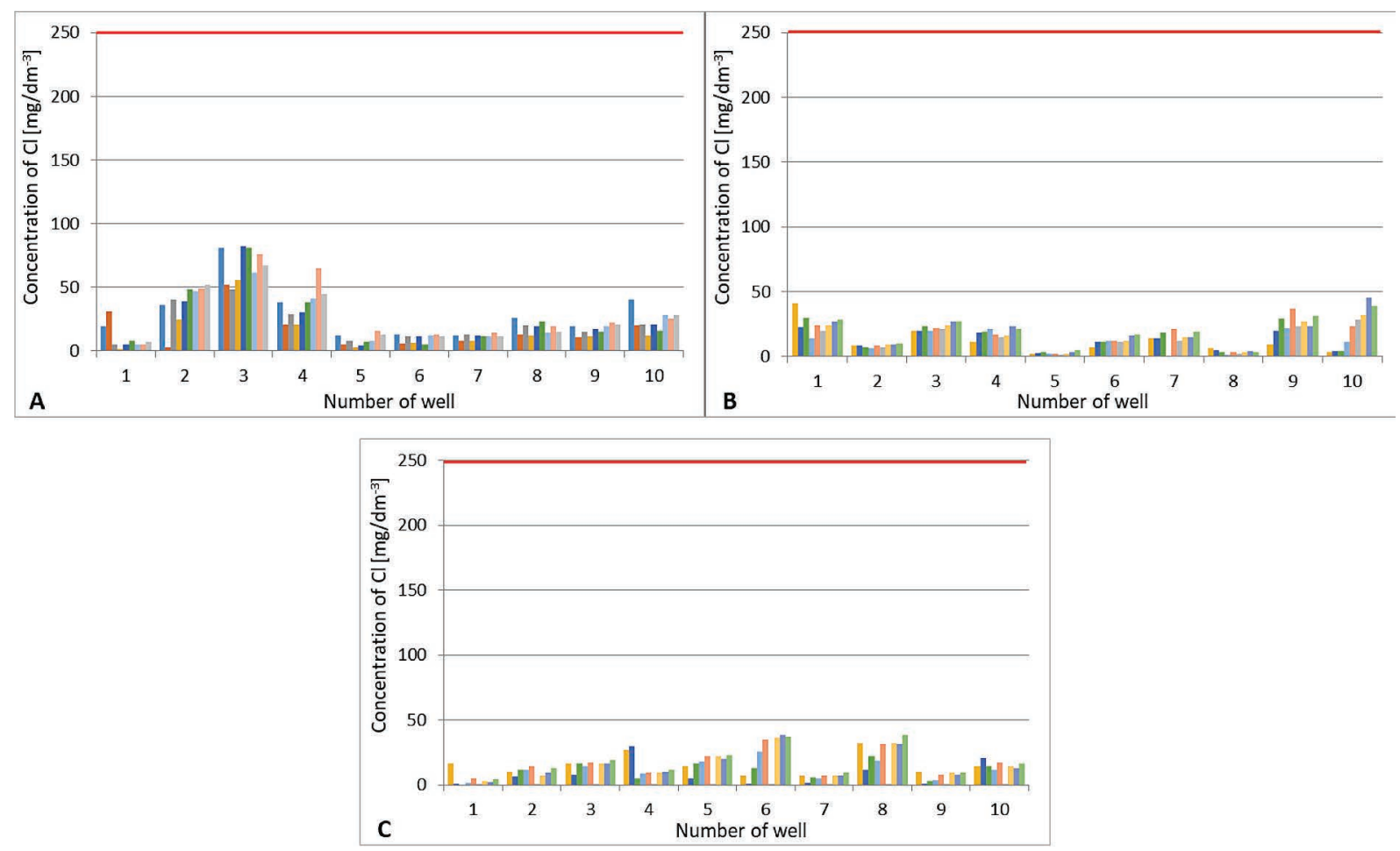

Figure 9. Concentration of chloride in the well waters (A - Drelów; B - Dębowa Kłoda; C - Urszulin) Notation: continuous red line - Polish requirements for drinking water $\left(250 \mathrm{mg} / \mathrm{dm}^{-3}\right)$

[Regulation of the Minister of Health 2017]

was exceeded multiple times in the waters from wells in all the considered communes, most often in Dębowa Kłoda (Figure 11). In Drelów, elevated iron content was observed in wells no. 1 , 2, 4, and 10, in Dębowa Kłoda in wells no. 1, 2, $3,5,7,8,9$, and 10 , whereas in Urszulin in wells no. $1,4,5,7,9$, and 10 .

The high content of iron in the waters from wells located in the considered communes was not caused by the wastewater discharged from the treatment plants with drainage system. Instead, it was probably caused by the hydrogeological conditions and weathering processes of iron-rich rocks [Kowal, Świderska-Bróż 2009].

Manganese. In the analyzed samples of well water, the concentrations of manganese ranged from 0.03 to $0.73 \mathrm{mg} / \mathrm{dm}^{3}$ in Drelów, from 0.04 to $0.19 \mathrm{mg} / \mathrm{dm}^{3}$ in Dębowa Kłoda, and from 0.03 to $0.26 \mathrm{mg} / \mathrm{dm}^{3}$ in Urszulin (Tables 7-9). The permissible content of manganese, determined in the Regulation of the Minister of Health [2017] for the water intended for human consumption at $0.05 \mathrm{mg} / \mathrm{dm}^{3}$, was exceeded in all well waters in the analyzed communes (Figure 12).

As it was mentioned earlier, the soils of the selected communes in the Lublin province are rich in manganese; hence, its presence in the analyzed waters is probably the result of natural processes, connected with the infiltration of this element from rocks and minerals.

Total hardness. According to the Regulation of the Minister of Health [2017], the hardness of water intended for human consumption should be within the range of $60-500 \mathrm{mg}$ $\mathrm{CaCO}_{3} / \mathrm{dm}^{3}$. In the case of the investigated waters, total hardness was within the required range, specifically from 106.60 to $360.55 \mathrm{mg} /$ $\mathrm{dm}^{3}$ in Drelów, from 130.73 to $274.52 \mathrm{mg} / \mathrm{dm}^{3}$ in Dębowa Kłoda, and from 112.59 to 416.12 $\mathrm{mg} / \mathrm{dm}^{3}$ in Urszulin (Tables 7-9).

Coliform and fecal coliform bacteria in well waters. Tables 10-12 present the count of coliform and fecal coliform bacteria in the waters from wells in the 3 selected communes in the Lublin province.

Diversified count of coliform and fecal coliform bacteria was noted in the well waters in particular communes. In the case of points no. 2, 3 and 5 in Urszulin as well as points no. 2, 4, and 6 in Drelów, no coliform or fecal coliform bacteria were noted whatsoever. On the basis of the microbiological analysis of water, the most coliform bacteria were observed in Dębowa Kłoda, with their count in $100 \mathrm{ml}$ ranging from $3.75 \cdot 10^{2}$ in point no. 8 to $14.25 \cdot 10^{3}$ in point no. 1 (Table 11). A lower count 

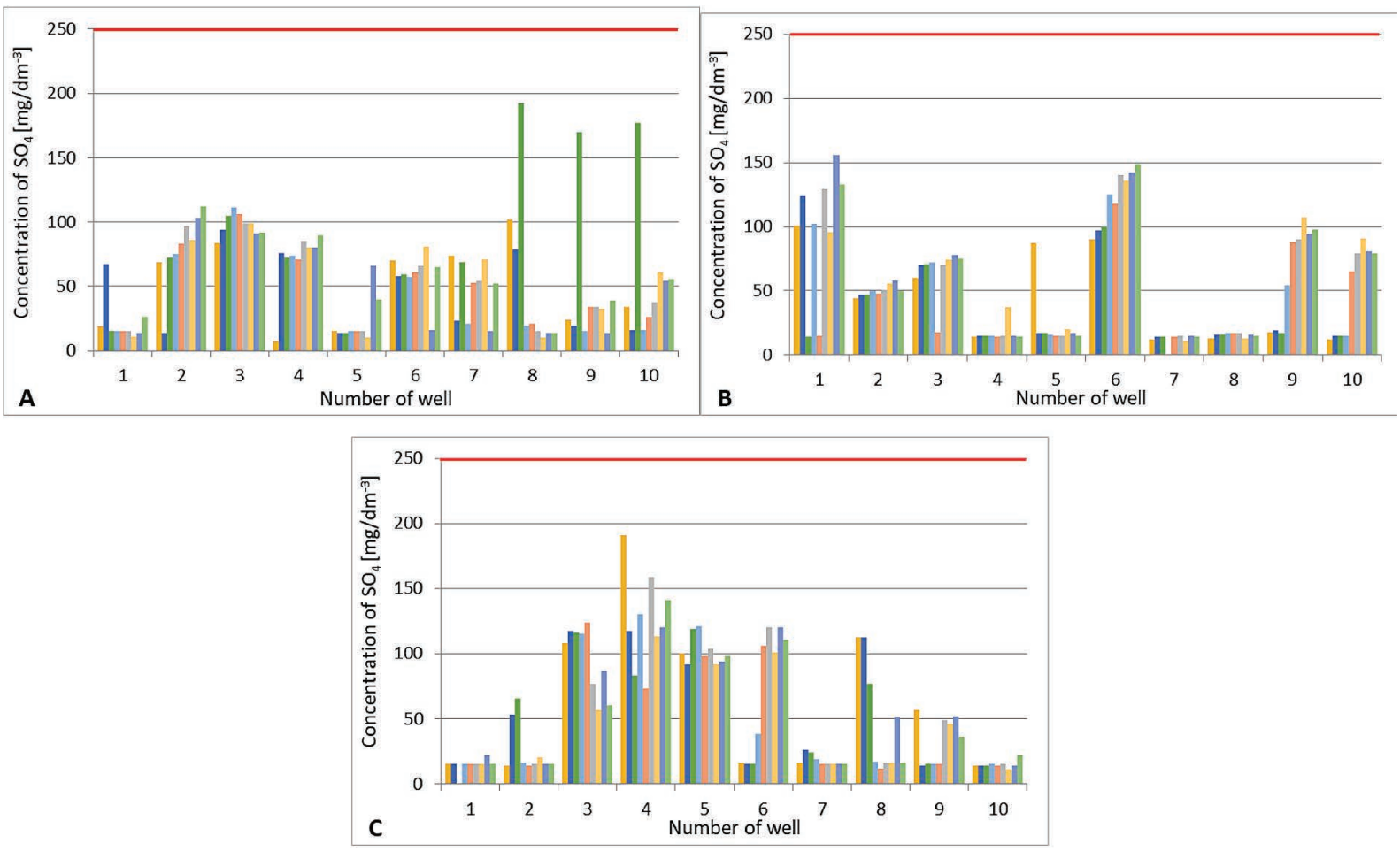

Figure 10. Concentration of sulfates in the well waters (A - Drelów; B - Dębowa Kłoda; C - Urszulin) Notation: continuous red line - Polish requirements for drinking water $\left(250 \mathrm{mg} / \mathrm{dm}^{-3}\right)$

[Regulation of the Minister of Health 2017]
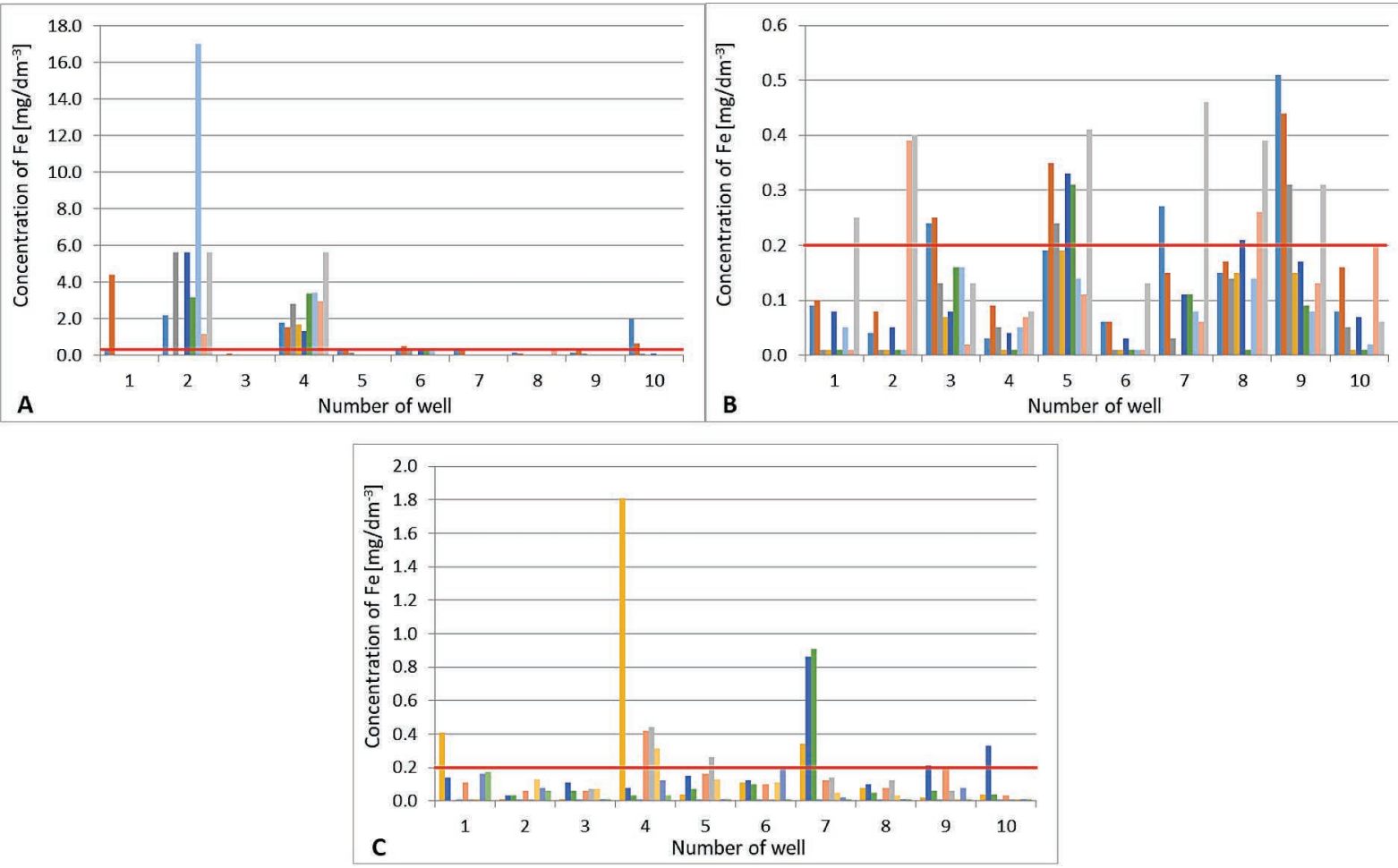

Figure 11. Concentration of iron in the well waters (A - Drelów; B - Dębowa Kłoda; C - Urszulin) Notation: continuous red line - Polish requirements for drinking water $\left(0.2 \mathrm{mg} / \mathrm{dm}^{-3}\right)$

[Regulation of the Minister of Health 2017]

of coliform bacteria was indicated in Urszulin and Drelów, ranging from $8 \cdot 10^{2}$ to $13.12 \cdot 10^{3}$ as well as from $7 \cdot 10^{2}$ to $13.17 \cdot 10^{3}$, respectively (Tables 10 and 12). The count of fecal coliform in the considered water samples was much lower and ranged from $1,0 \cdot 10^{2}$ to $6,35 \cdot 10^{3}$ in $100 \mathrm{ml}$, with the greatest 

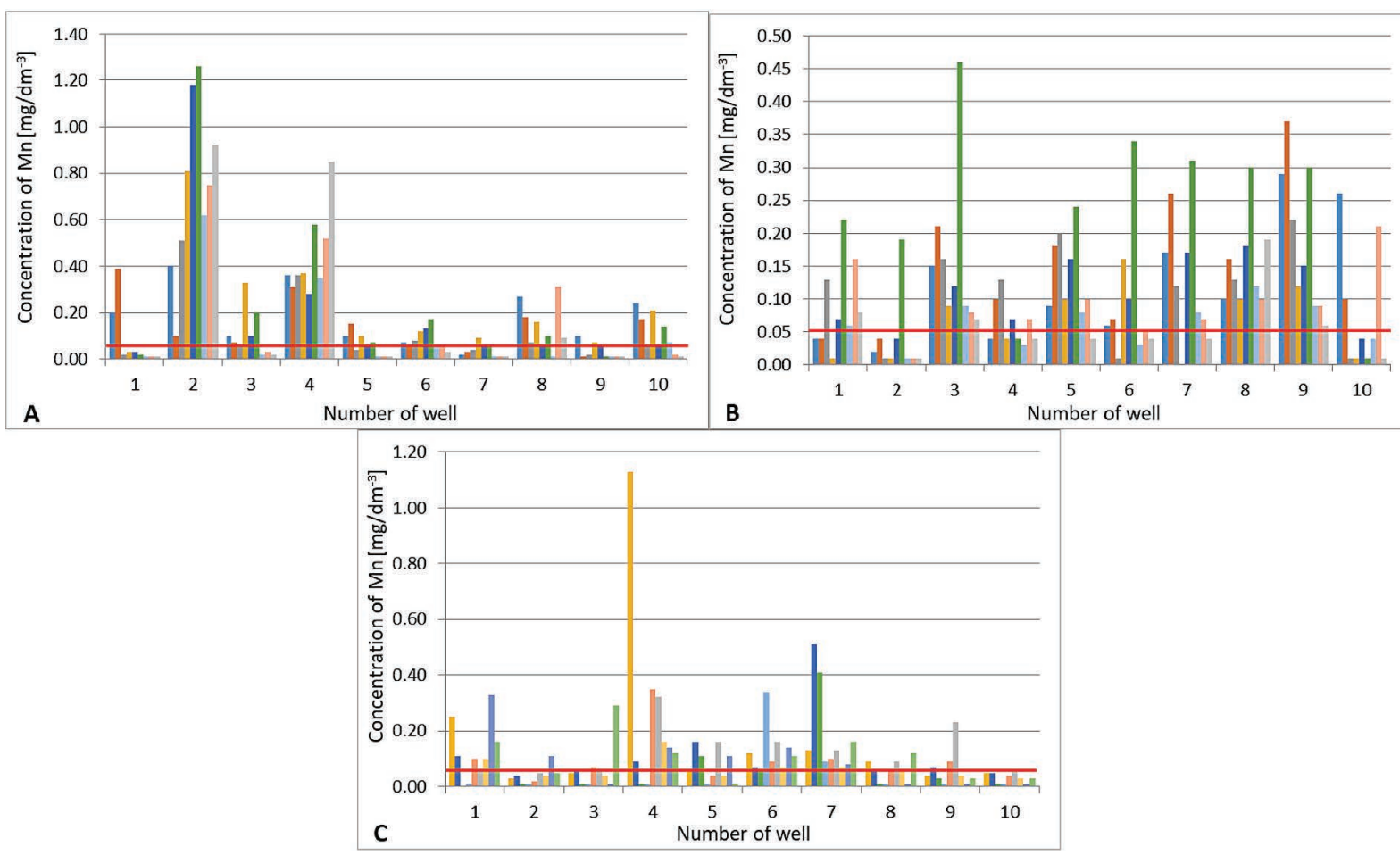

Figure 12. Concentration of manganese in the well waters (A - Drelów; B - Dębowa Kłoda; C - Urszulin) Notation: continuous red line - Polish requirements for drinking water $\left(0.05 \mathrm{mg} / \mathrm{dm}^{-3}\right)$

[Regulation of the Minister of Health 2017]

Table 10. Count of coliform (incubation at $37^{\circ} \mathrm{C}$ ) and fecal coliform bacteria (incubation at $44^{\circ} \mathrm{C}$ ) in MPN/100 ml of water from wells in Drelów

\begin{tabular}{|c|c|c|c|c|c|c|c|c|}
\hline \multirow{2}{*}{ Point } & \multicolumn{4}{c}{ Coliform bacteria $\left(37^{\circ} \mathrm{C}\right)(\mathrm{MPN} / 100 \mathrm{ml})$} & \multicolumn{3}{c|}{ Fecal coliform bacteria $\left(44^{\circ} \mathrm{C}\right)(\mathrm{MPN} / 100 \mathrm{ml})$} \\
\cline { 2 - 9 } & $\mathrm{VI}$ & $\mathrm{VIII}$ & $\mathrm{X}$ & $\mathrm{XI}$ & $\mathrm{VI}$ & $\mathrm{VIII}$ & $\mathrm{X}$ & $\mathrm{XI}$ \\
\hline 1 & $2.5 \cdot 10^{3}$ & $4 \cdot 10^{2}$ & $4 \cdot 10^{2}$ & $4 \cdot 10^{2}$ & 0 & 0 & $4 \cdot 10^{2}$ & 0 \\
\hline 2 & 0 & 0 & 0 & 0 & 0 & 0 & 0 & 0 \\
\hline 3 & $4.5 \cdot 10^{3}$ & $2.5 \cdot 10^{3}$ & $4.5 \cdot 10^{3}$ & $2.5 \cdot 10^{3}$ & 0 & 0 & $4 \cdot 10^{2}$ & 0 \\
\hline 4 & 0 & 0 & 0 & 0 & 0 & 0 & 0 & 0 \\
\hline 5 & 0 & $7 \cdot 10^{2}$ & 0 & 0 & 0 & 0 & 0 & 0 \\
\hline 6 & 0 & 0 & 0 & 0 & 0 & 0 & 0 & 0 \\
\hline 7 & 0 & $4 \cdot 10^{2}$ & $4.5 \cdot 10^{3}$ & $4 \cdot 10^{2}$ & 0 & 0 & $4 \cdot 10^{2}$ & 0 \\
\hline 8 & $4.5 \cdot 10^{3}$ & $7 \cdot 10^{2}$ & $4.5 \cdot 10^{4}$ & $2.5 \cdot 10^{3}$ & 0 & 0 & 0 & 0 \\
\hline 9 & $2.5 \cdot 10^{3}$ & $2.5 \cdot 10^{3}$ & 0 & 0 & 0 & 0 & 0 & 0 \\
\hline 10 & 0 & 0 & $2.5 \cdot 10^{3}$ & $4 \cdot 10^{2}$ & 0 & 0 & 0 & 0 \\
\hline
\end{tabular}

Table 11. Count of coliform (incubation at $37^{\circ} \mathrm{C}$ ) and fecal coliform bacteria (incubation at $44^{\circ} \mathrm{C}$ ) in $\mathrm{MPN} / 100 \mathrm{ml}$ of water from wells in Dębowa Kłoda

\begin{tabular}{|c|c|c|c|c|c|c|c|c|}
\hline \multirow{2}{*}{ Point } & \multicolumn{4}{c}{ Coliform bacteria $\left(37^{\circ} \mathrm{C}\right)(\mathrm{MPN} / 100 \mathrm{ml})$} & \multicolumn{3}{c|}{ Fecal coliform bacteria $\left(44^{\circ} \mathrm{C}\right)(\mathrm{MPN} / 100 \mathrm{ml})$} \\
\cline { 2 - 9 } & $\mathrm{VI}$ & $\mathrm{VIII}$ & $\mathrm{X}$ & $\mathrm{XI}$ & $\mathrm{VI}$ & $\mathrm{VIII}$ & $\mathrm{X}$ & $\mathrm{XI}$ \\
\hline 1 & $2.5 \cdot 10^{3}$ & $2.5 \cdot 10^{4}$ & $2.5 \cdot 10^{4}$ & $4.5 \cdot 10^{3}$ & 0 & $4 \cdot 10^{2}$ & 4500 & 0 \\
\hline 2 & 0 & $2.5 \cdot 10^{3}$ & $4.5 \cdot 10^{3}$ & 0 & 0 & 0 & 0 & 0 \\
\hline 3 & $2.5 \cdot 10^{4}$ & $2.5 \cdot 10^{3}$ & $4.5 \cdot 10^{3}$ & 0 & $2.5 \cdot 10^{4}$ & 0 & $4 \cdot 10^{2}$ & 0 \\
\hline 4 & $4 \cdot 10^{2}$ & $4 \cdot 10^{2}$ & $3 \cdot 10^{2}$ & $2.5 \cdot 10^{3}$ & 0 & 0 & 0 & $7 \cdot 10^{2}$ \\
\hline 5 & $7 \cdot 10^{2}$ & $4 \cdot 10^{2}$ & $7.5 \cdot 10^{3}$ & 0 & 0 & 0 & $7 \cdot 10^{2}$ & 0 \\
\hline 6 & $7.5 \cdot 10^{3}$ & 0 & $1.4 \cdot 10^{5}$ & $2.5 \cdot 10^{3}$ & 0 & 0 & $1.6 \cdot 10^{4}$ & $2.5 \cdot 10^{3}$ \\
\hline 7 & $4 \cdot 10^{2}$ & - & $2.5 \cdot 10^{4}$ & 0 & 0 & - & $7 \cdot 10^{2}$ & 0 \\
\hline 8 & $4 \cdot 10^{2}$ & $7 \cdot 10^{2}$ & $4 \cdot 10^{2}$ & 0 & 0 & $4 \cdot 10^{2}$ & 0 & 0 \\
\hline 9 & $4 \cdot 10^{2}$ & $4.5 \cdot 10^{3}$ & $2.5 \cdot 10^{4}$ & $4.5 \cdot 10^{3}$ & $4 \cdot 10^{2}$ & 0 & $2.5 \cdot 10^{3}$ & 0 \\
\hline 10 & 0 & $2.5 \cdot 10^{3}$ & $2.5 \cdot 10^{4}$ & $4.5 \cdot 10^{3}$ & 0 & 0 & $7 \cdot 10^{2}$ & 0 \\
\hline
\end{tabular}


Table 12. Count of coliform (incubation at $37^{\circ} \mathrm{C}$ ) and fecal coliform bacteria (incubation at $44^{\circ} \mathrm{C}$ ) in $\mathrm{MPN} / 100 \mathrm{ml}$ of water from wells in Urszulin

\begin{tabular}{|c|c|c|c|c|c|c|c|c|}
\hline \multirow{2}{*}{ Point } & \multicolumn{4}{c}{ Coliform bacteria $\left(37^{\circ} \mathrm{C}\right)(\mathrm{MPN} / 100 \mathrm{ml})$} & \multicolumn{3}{c|}{ Fecal coliform bacteria $\left(44^{\circ} \mathrm{C}\right)(\mathrm{MPN} / 100 \mathrm{ml})$} \\
\cline { 2 - 9 } & $\mathrm{VI}$ & $\mathrm{VIII}$ & $\mathrm{X}$ & $\mathrm{XI}$ & $\mathrm{VI}$ & $\mathrm{VIII}$ & $\mathrm{X}$ & $\mathrm{XI}$ \\
\hline 1 & $2.5 \cdot 10^{4}$ & $1.4 \cdot 10^{5}$ & $4.5 \cdot 10^{3}$ & $2.5 \cdot 10^{3}$ & 0 & 0 & 0 & 0 \\
\hline 2 & 0 & 0 & 0 & 0 & 0 & 0 & 0 & 0 \\
\hline 3 & 0 & 0 & 0 & 0 & 0 & 0 & 0 & 0 \\
\hline 4 & 2500 & 0 & $4 \cdot 10^{2}$ & $2.5 \cdot 10^{3}$ & 0 & 0 & $3 \cdot 10^{2}$ & 0 \\
\hline 5 & 0 & 0 & 0 & 0 & 0 & 0 & 0 & 0 \\
\hline 6 & $4 \cdot 10^{2}$ & $2.5 \cdot 10^{3}$ & $2.5 \cdot 10^{4}$ & $2.5 \cdot 10^{3}$ & 0 & 0 & 0 & 0 \\
\hline 7 & $4.5 \cdot 10^{3}$ & $2.5 \cdot 10^{3}$ & $4.5 \cdot 10^{3}$ & 0 & $4 \cdot 10^{2}$ & 0 & 0 & 0 \\
\hline 8 & $2.5 \cdot 10^{3}$ & $2.5 \cdot 10^{4}$ & $2.5 \cdot 10^{4}$ & 0 & 0 & 0 & 0 & 0 \\
\hline 9 & $2.5 \cdot 10^{3}$ & $4 \cdot 10^{2}$ & $4.5 \cdot 10^{3}$ & 0 & 0 & 0 & 0 & 0 \\
\hline 10 & $2.5 \cdot 10^{3}$ & 0 & $7 \cdot 10^{2}$ & 0 & 0 & 0 & 0 & 0 \\
\hline
\end{tabular}

number observed in Drelów, point no. $3\left(6.35 \cdot 10^{3}\right)$ and $6\left(4.62 \cdot 10^{3}\right)$ (Table 10$)$.

Water contributes to a rapid spread of infectious diseases, originating from human feces, found i.a. in household wastewater as well as animal excrements contained in the livestock wastewater [Michałkiewicz et al. 2011]. The obtained research results indicate that the quality of well waters in the selected communes in the Lublin province is poor (Tables 10-12) and in many cases does not meet the requirements found in the Regulation of the Minister of Health [2017]. Similar conclusions were also drawn by Jóźwiakowski et al. [2014]. While analyzing the impact of household wastewater treatment plants on the quality of groundwater, they indicated the presence of coliform bacteria with count up to $7 \cdot 10^{5}$ in $100 \mathrm{ml}$ [Jóźwiakowski et al. 2014]. The presence of fecal coliform bacteria in the investigated waters clearly indicates the contamination with excrements and exposure to anthropogenic pollution, especially the inflow of insufficiently treated wastewater [Jóźwiakowski et al. 2014; Somaratne, Hallas 2015].

\section{CONCLUSIONS}

The mechanically treated wastewater discharged to drainage systems in vicinity of groundwater intakes was characterized by very high content of organic and inorganic pollutants, including the nitrogen and phosphorus compounds, chlorides as well as substantial count of coliform and fecal coliform bacteria.

The groundwater from shallow individual intakes in the area of selected communes of the Lublin province was characterized by elevated concentrations of ammonia and nitrites. Moreover, the waters from some intakes indicated extremely poor microbiological condition, mainly due to the presence of fecal coliform bacteria, which are unacceptable in the water intended for consumption.

In the majority of cases, the analyzed groundwater did not meet the basic requirements for potable water and the fact that it is not used for consumption does not affect its general assessment. The presence of microbiological pollution of fecal origin in the groundwater from dug wells indicates the direct influence of household wastewater, discharged to soil via drainage systems of household treatment plants. The presence of nitrogen compounds, ammonia and nitrites may be similarly related to this situation.

The impact of wastewater discharged to soil via drainage systems on the quality of shallow groundwater in also supported by the close proximity of household wastewater treatment plants in relation to water intakes, which does not meet the current legal regulations. The high level of water tables and low thickness of protective geological layers could also have contributed to the migration of wastewater to groundwater. This is supported by the relatively good quality of waters from two deep water wells, especially the lack of microbiological contamination. In this case, iron and manganese constituted exceptions, but their elevated concentrations was related to natural processes.

High content of pollutants in the wastewater discharged to soil via drainage systems and high probability of groundwater pollution indicate that these systems do not fulfill their ecological function and should not be employed as stand-alone installations for treating wastewater. This is especially true in the case of the areas with unfavorable soil and hydrological conditions as well as the areas with low water supply coverage, where the use of waters from shallow individual intakes is suggested for consumption. 
Taking into account the obtained research results, it advisable to take the legal and administrative actions in order to limit the application of installations with drainage systems as well as reduce their negative impact on the environment. This includes, i.a. applying the requirements which are currently valid for the treatment plants below 2000 equivalent number of inhabitants in the case of all household treatment plants as well as introducing the duty of controlling their operation. Should the nation-wide legal changes prove to be impossible to implement, the strategy for the development of sewage management should be revised at a county level. This pertains especially to the principles for verifying the construction notifications for household wastewater treatment plants and the preferred technological solutions ensuring the achievement of full ecological effect, which are simultaneously simple and cheap to operate. Out of the solutions currently available on the market, these criteria are best met by, i.a. sand filters and constructed wetland systems.

\section{Acknowledgements}

The research for this publication was financed from the funds of the Regional Fund for Environmental Protection and Water Management in Lublin under the contract No. 7/2020/D/IN as a project entitled "The impact of home sewage treatment plants with infiltrating drainage on the quality of groundwater in the Lubelskie Voivodeship".

\section{REFERENCES}

1. Announcement of the Marshal of the Sejm of the Republic of Poland of 22 July 2020 on the publication of the uniform text of the Act on maintaining cleanliness and order in communes, Warsaw, 24 August 2020 (item 1439) (in Polish).

2. Anastasi E. M., Matthews B., Stratton H. M., Katouli M. 2012. Pathogenic Escherichia coli found in sewage treatment plants and environmental waters. Applied and environmental microbiology, 78(16), 55365541, https://doi.org/10.1128/AEM.00657-12

3. Budzińska K., Berleć K., Tarczykowski A., Pawlak P. 2007. Estimation of efficiency of contamination removal from waste water by means of filtration drainage, 623-633 (in Polish).

4. Błażejewski R. 1995. Individual sanitation systems and groundwater. Water management 10, 238-240 (in Polish).

5. Bugajski P., Gajewska M., Jóźwiakowski K., Siwiec T. 2017. Technological solutions used in water and wastewater management in rural areas [In]: Jóźwiakowski K., Siuda W. (red.) Protection and development of water resources in rural areas. Foundation for the Development of Polish Agriculture. Warszawa, 55-70 (in Polish).

6. Cabral J.P. 2010. Water microbiology. Bacterial pathogens and water. International journal of environmental research and public health 7 (10), 3657 3703. https://doi.org/10.3390/ijerph7103657.

7. Dębowa Kłoda Commune. 2015. Development strategy of the Dębowa Kłoda commune for the years to come 2015-2020. (https://absta.pl/strategia-rozwoju-gminydbowa-koda-na-lata-2015-2020.html) (in Polish).

8. District Council in Biała Podlaska. 2018. Development strategy of the Biała Podlaska country for the years 2018-2026. Biała Podlaska (in Polish).

9. Dojlido J., Dożańska W., Hermanowicz W., Koziorowski B., Zerbe J. 1999. Physicochemical examination of water and sewage. Arkady, Warszawa (in Polish).

10. Dymaczewski Z., Oleszkiewicz J., Sozański M. 1997. A wastewater treatment plant operator's guide. Publisher: PZITS, Poznań, p. 618 (in Polish).

11. GUS 2019a. Environmental Protection 2019. Warszawa (in Polish).

12. GUS 2019b. Housing economy and municipal infrastructure in 2018, Warszawa (in Polish).

13. Heidrich Z., Stańko G. 2007. Lexicon of home sewage treatment plants. Publishing House Seidel Przywecki, p. 128 (in Polish).

14. Heidrich Z., Kalenik M., Podedworna J., Stańko G. 2008. Village sanitation. Publishing House SeidelPrzywecki, p. 374.

15. Jarvie H.P., Neal C., Withers P.J.A. 2006. Sewageeffluent phosphorus: A greater risk to river eutrophication than agricultural phosphorus? Science of The Total Environment, 360, 246-253.

16. Jóźwiakowska K., Brodowska N., Wójcik M., Listosz A., MicekA., Marzec M., Pochwatka P. 2020. The Concentration of the salinity indicators in the water of the Bystrzyca river on the area of Lublin city in Poland. Journal of Ecological Engineering, 21 (7), 58-67.

17. Jóźwiakowska K., Marzec M. 2020. The condition of the sanitary infrastructure in the Bialski district in Poland and the need for its development. Jornal of Ecological Engineering, 21 (5), 155-163.

18. Jóźwiakowski K. 2003. Analysis of the effects of domestic wastewater treatment in household sewage treatment plants in rural areas on the example of selected facilities in the Lublin voivodeship. Acta Scientiarum Polonorum, ser. Formatio Circumiectus, 2 (1), 3-14 (in Polish).

19. Jóźwiakowski K. 2012a. Studies on the efficiency of sewage treatment in choosen constructed wetland systems. Infrastructure and ecology of rural areas, 1, p. 232 (in Polish).

20. Jóźwiakowski K. 2012b. Household wastewater treatment plants in rural areas - part I, Civil engineer 10, 57-60 (in Polish).

21. Jóźwiakowski K., Marzec M., Kowalczyk-Juśko A., Gizińska-Górna M., Pytka-Woszczyło A., Malik A., 
Listosz A., Gajewska M. 2019. 25 years of research and experiences about the application of constructed wetlands in southeastern Poland. Ecological Engineering, 127, 440-453.

22. Jóźwiakowski K., Mucha Z., Generowicz A., Baran S., Bielińska J., Wójcik W. 2015. The use of multi-criteria analysis for selection of technology for a household WWTP compatible with sustainable development. Arch. Environ. Prot., 3, 76-82.

23. Jóźwiakowski K., Podbrożna D., Kopczacka K., Marzec M., Kowalczyk-Juśko A., Pochwatka P., Listosz A., Malik A. 2017. The State of Water and Wastewater Management in the Municipalities of the Polesie National Park. Journal of Ecological Engineering, 18 (6), 191-199.

24. Jóźwiakowski K., Podbrożna D., Kopczacka K., Jaguś M., Marzec M., Listosz A., Pochwatka P., Kowalczyk-Juśko A., Malik A. 2018. The State of Water and Wastewater Management in the Municipalities of the Roztocze National Park. Journal of Ecological Engineering, 19 (2), 255-262.

25. Jóźwiakowski K., Pytka A., Marzec M., Gizińska M., Dąbek J., Głaz B., Sławińska A. 2012. Development of water and wastewater infrastructure in Lublin province in 2000-2011. Infrastructure and Ecology of Rural Areas. PAN. Branch in Kraków. Technical Rural Infrastructure Commission, 3/I/2012, 73-86 (in Polish).

26. Jóźwiakowski K., Steszuk A., Pieńko A., Marzec M., Pytka A., Gizińska M., Sosnowska B., Ozonek J. 2014. Evaluation of the impact of wastewater treatment plants with drainage system on the quality of groundwater in dug and deep wells. Ecological Engineering, 39, 74-84 (in Polish).

27. Jucherski A., Walczowski A. 2001. Drainage drainage. Purification or discharge of treated sewage into the soil. Wiadomości Melioracyjne i Łąkarskie, Vol. 3 (390), 131-132 (in Polish).

28. Kiryluk A. 2011. Concentrations of nitrates (V) in well waters in the rural areas of Podlasie province and the pssesment of inhabitants' health risk. Ecological Chemistry and Engineering A, 18 (2), 207-218.

29. Kowal A.L., Świderska-Bróż M. 2009. Water purification Theoretical and technological foundations, processes and devices. Polish Scientific Publishers PWN, Warszawa, p. 802 (in Polish).

30. Micek A., Jóźwiakowski K., Marzec M., Listosz A., Malik A. 2020. Efficiency of pollution removal in preliminary settling tanks of household wastewater treatment plants in the Roztocze National Park. Journal of Ecological Engineering, 21 (5), 9-18.

31. Micek A., Marzec M., Jóźwiakowska K., Pochwatka P. 2018. The condition of sanitary infrastructure in the Parczew district and the need for its development. Journal of Ecological Engineering, 19 (5), 107-115.

32. Michałkiewicz M., Jeż-Walkowiak J., Dymaczewski Z., Sozański M.M. 2011. Disinfection of sewage. Ecological Engineering, 24, 38-51 (in Polish).

33. Mucha Z., Mikosz J. 2009. Rational application of small wastewater treatment plants according to sustainability criteria. Technical Journal. Environment,
106, Vol. 2-Śs, 91-100 (in Polish).

34. Obarska-Pempkowiak H. 2005. Constructed Wetland System - UE Requirements. Scientific Papers of the Faculty of Civil and Environmental Engineering, Koszalin University of Technology, Vol. 22, 77-97 (in Polish).

35. Orlik T., Jóźwiakowski K. 2003. Assessment of the operation of two household sewage treatment plants of BATEX type with infiltration drainage. Agricultural Engineering, 3 (45), Vol 1, 109-119 (in Polish).

36. Paluch J., Pulikowski K. 2004. Selected problems related to the construction of farm sewage treatment plants with drainage drainage. Wiad. Mel. i Łąk., Vol. 4, 191-198 (in Polish).

37. Pawełek J., Bugajski P. 2017. Development of home sewage treatment plants in Poland - advantages and disadvantages of solutions. Acta Sci. Pol. Formatio Circumiectus, 16 (2), 3-14 (in Polish).

38. Pawęska K., Malczewska B., Zyglińska B. 2012. Characteristic of wellwaters with particular consideration of nitrogen compounds in Przezdziedza village. Proceedings of EC Opole, 6 (1), 253-260 (in Polish).

39. Raczuk J., Sarnowska K. 2002. Water quality of rural wells in selected communes of the Lubelskie Voivodeship. Archives of Environmental Protection, Institute of Fundamentals of Environmental Engineering PAN, 28 (3), 63-75.

40. Regulation of the Minister of Health of 7 December 2017 on the quality of water intended for human consumption (No 2017, item 2294) (in Polish).

41. Regulation of the Minister of Maritime Economy and Inland Navigation of 12 July 2019 on substances which are particularly harmful to the aquatic environment and the conditions to be met when discharging wastewater into water or soil and when discharging rainwater or snowmelt into water or water installations (No 2019, item 1311) (in Polish).

42. Skrzypiec K., Bejnarowicz A., Gajewska M. 2017. Wastewater treatment and management solutions for non-urban areas. Small wastewater treatment plants in accordance with the principles of sustainable development. Installation Market, 4, 85-89 (in Polish).

43. Somaratne N., Hallas G. 2015. Review of risk status of groundwater supply wells by tracing the source of coliform contamination. Water, 7, 3878-3905.

44. US in Lublin 2019. Statistical Yearbook of the Lubelskie Voivodeship. Lublin (in Polish).

45. Urszulin Commune Office 2015. Strategy for the sustainable development of the Urszulin Commune for 2015-2020 with a perspective until 2023. Urszulin (in Polish).

46. Water law 2017. The Act of July 20.2017. (No 2017, item 1566) (in Polish).

47. Walczowski A. 2013. Home sewage treatment plants for the sustainable development of rural areas. In: Polish Ecological Club, City Circle in Gliwice. Technologies and devices for home sewage treatment plants, Gliwice (in Polish). 